\title{
Nanomaterials: Solutions to Water-Concomitant Challenges
}

\author{
Shaik Anwar Ahamed Nabeela Nasreen ${ }^{1}$, Subramanian Sundarrajan ${ }^{1}$, \\ Syed Abdulrahim Syed Nizar ${ }^{2}$ and Seeram Ramakrishna ${ }^{1,2, *}$ \\ 1 Department of Mechanical Engineering, National University of Singapore, 2 Engineering Drive 3, \\ Singapore 117581, Singapore; mpesaan@nus.edu.sg (S.A.A.N.N.); sundar@nus.edu.sg (S.S.) \\ 2 NUS Nanoscience and Nanotechnology Institute, National University of Singapore, 2 Engineering Drive 3, \\ Singapore 117581, Singapore; nnisasn@nus.edu.sg \\ * Correspondence: seeram@nus.edu.sg
}

Received: 4 February 2019; Accepted: 11 March 2019; Published: 14 March 2019

\begin{abstract}
Plenty of fresh water resources are still inaccessible for human use. Calamities such as pollution, climate change, and global warming pose serious threats to the fresh water system. Although many naturally and synthetically grown materials have been taken up to resolve these issues, there is still plenty of room for enhancements in technology and material perspectives to maximize resources and to minimize harm. Considering the challenges related to the purification of water, materials in the form of nanofiber membranes and nanomaterials have made tremendous contributions to water purification and filtration. Nanofiber membranes made of synthetic polymer nanofibers, ceramic membranes etc., metal oxides in various morphologies, and carbonaceous materials were explored in relation to waste removal from water. In this review, we have discussed a few key materials that have shown effectiveness in removing pollutants from waste water, enabling solutions to existing problems in obtaining clean drinking water.
\end{abstract}

Keywords: pollutant; electrospinning; nanofiber membranes; metal oxides; carbonaceous materials; water filtration

\section{Introduction}

Indicators of the United Nations Water statistics shows that the Earth's entire water capacity is 1.4 billion $\mathrm{km}^{3}$. About $2.5 \%$ of the total volume is accounted for by fresh water, which totals about 35 million $\mathrm{km}^{3}$ in volume, with the remaining water resource existing as saline water. Snow and ice in the Arctic and Antarctic cover $70 \%$ of the available fresh water in mountainous regions ( 24 million $\mathrm{km}^{3}$ ). Shallow and deep ground water basins lock up approximately $30 \%$ of the remaining water, which is up to $2 \mathrm{~km}^{3}$. Only $0.3 \%$ accounts for rivers and lakes, for a total volume of $105,000 \mathrm{~km}^{3}$ [1]. Overall, from the $97 \%$ available fresh water, about $70 \%$ is used for irrigation, $22 \%$ for industrial use, and $8 \%$ for domestic purposes. The world's seven billion people consume about $54 \%$ of the accessible fresh water from underground aquifers, rivers, and lakes, and the remaining 46\% left unused. Almost $97 \%$ of global water resources are from seas and oceans. Though we have enough water resources, many potential hazards such as global warming due to overpopulation, urbanization, and industrial growth affect the availability of water resources. Based on the demands of population growth, many sectors are expanding, imposing excessive demands on water, leading to a much-expected depletion of water and its resources.

Industrialization and urbanization accumulate pollutants such as heavy metal ions [2], dyes [3], pharmaceutical wastes [4], etc. in water. Toxic heavy metals like $\mathrm{Cd}, \mathrm{As}, \mathrm{Hg}$, and $\mathrm{Pb}$ in natural potable water exceed the permissible tolerance limit. Humans contact with such heavy metals poses a major 
health risk, due to its carcinogenic and toxic effects [5]. In recent years, the removal of heavy metals has been an extensive research topic. These heavy metals are not only causing pollution to water, but they are also life-threatening [6]. Some of the most toxic and carcinogenic heavy metals include $\mathrm{Pb}$ (II) [7], Cd(II) [8], As(II) [9], Cu(II) [10], Ni(II) [11], As(III) [12], and Cr(VI) [13] and so on. Some of the metal cations can even cause damage to the central nervous system and kidneys in humans.

Another pollutant which is the most life threatening to human is dyes. Textile industries are the foremost source of dye pollutants in water contamination. Dye removal is an extremely important issue to deal with, as it is well-understood that it causes serious harm to humans. Some of the key consequences of dyes include the inhibition of light to penetrate into water, which in turn hampers photosynthesis in aquatic plants. Carcinogenic effects have also been observed in a few dyes, and their degraded products are present in surface water [14]. Hence, it is important to clean or to pretreat these dye effluents before discharging them into any water resources. Reports from the Odour Index, managed by SDC (Society of Dyers and Colorists) shows there are about 100,000 different types of dyes that are synthesized and commercially available [15]. An estimated 700,000 tonnes of dyes are produced worldwide. About $2.4 \%$ of this total run off as industrial waste water after use; it is difficult to treat organic dyes through normal procedures, and it is highly recommended that they be degraded by chemical methods. The majority of dyes are dangerous, e.g., methyl red is a mono azo dye that is used in textiles and in other commercial products, which poses serious damage to the digestive tract, causing irritation if it is inhaled or swallowed, as well as skin and pharyngeal sensitization, and so on [16]. Microbes in the water, as pathogens, can pose a public health hazard, leading to severe gastrointestinal illnesses. Coagulation [17], flocculation [18], biological oxidation [19], activated carbon [20], and chemical precipitation [21] adsorption are a few common methods that are available for color removal [22]. Similarly, oil spills in various forms are also a cause for water pollution. Due to many modern techniques, oil spills [23] from industries and bilge water [24] increase the level of contamination in water resources. It is equally important to remove oil, which affects the food chain if it persists in the long-term.

It is well-understood that microbes such as bacteria, viruses, and other biological entities contaminate the air, water, and soil, and thereby create serious harmful effects to humans and other living things. With an increasing population, awareness of public health is needed, due to the pathogenic effects caused by microorganisms. This leads to an increase in the requirement for antibacterial materials in medicines, food, etc. Millions of people in developing countries die due to the non-accessibility of pathogen-free drinking water. Even chlorination, which is used to decontaminate water, will also react with naturally-occurring organic materials in water and produce by-products that are highly hazardous. Human infections by certain bacteria and protozoan parasites are generally a result of contaminated water. Shigella spp., Vibrio cholera, Escherichia coli, Salmonella spp., and Campylobacter spp. are a few major pathogenic bacteria that are of concern in water. Waterborne protozoan pathogens include Naegleria fowleriand, Cryptosporidium parvum, Giardia duodenalis, Entamoeba histolytic, and Acanthamoeba spp.

Many new technologies have been established, but the majority are trial-and-error systems that forth potential and effective systems for desalination and pollutant removal. There are many scientific methods and materials that have been proposed and tested for the purification of water samples. Among those materials, nanomaterials in the form of nanoparticles or nanofibers with different morphologies have potential impacts for treating water, and have been observed to be very effective in removing pathogens, microbes, heavy metal ions, toxic metals, dye, oil, and other harmful organic solvents. In this review, we have discussed a few nanomaterials, such as the role of nanofiber membranes, in the effective removal of heavy metal ions, dyes, and oils. This discussion is further extended to study the antibacterial activities of such materials. Metal oxides and carbonaceous particles with high efficiency towards water purification are also discussed briefly. 
2. The Role of Nanomaterials for Effective Pollutant Removal-Heavy Metals, Dyes, and Antibacterial Activity

\subsection{Nanofiber Membranes as Pollutant Removal Media}

Nanofiber membranes are commonly studied materials for water filtration applications [25]. Many reviews on filtration using nanofiber membranes have been reported earlier by Ramalingam et al. [26] on air filtration, and by Shaik et al. [27] on water filtration. Polymer nanofibers that are fabricated by the electrospinning method have been shown to have unique properties in filtration studies.

The removal of microparticles by using polysulphone (PSu) nanofibers spun onto the backing material have been investigated by Renuga et al. [28]. High flux-prefilters with a maximum capability of loading were tested, due to the high porosity and surface area of the nanofiber membrane. The membrane had the ability to eradicate $99 \%$ of $10^{-7} \mu \mathrm{m}$ sized particles without any permanent fouling. With lower sized particles, it forms a cake, and hence this membrane was suggested for use as a prefilter for various microparticles. Similarly, high-flux microfiltration (MF) filters were made by using polyvinyl alcohol (PVA) polymers electrospun onto a microfibrous support, and crosslinked with glutaraldehyde in acetone. The reduction in the mean pore size from $0.3 \mu \mathrm{m}$ to $0.2 \mu \mathrm{m}$ enhanced the MF efficiency to about 3-7 times for nanofiber membranes when compared to the commercial membrane (Millipore) [29]. Also, an increase in the permeation flux improved the particle removal quite efficiently. Hongyang et al. [30] reported the synthesis of an ultrafine cellulose membrane of about 5-10 $\mu \mathrm{m}$ diameter, with a high surface volume and good chemical resistance. It showed an improved flux of about 2-3 times, compared to commercial membranes (gs9035 Millipore). Shaik et al. [31] reported a slight modification in the base polymer of an electrospun nanofiber membrane (ENM) that improved permeation flux. The hydrophilic poly (vinylidinefluoride)-hydroxyethyl methacrylate (PVDF-HEMA) membrane, developed by in situ polymerization of HEMA with PVDF, exhibited a high flux rate. A thin film coating was applied onto the electrospun membranes to reduce the pore size, which improved the flux to $60 \%$. It was concluded that hydrogen bonding and in-situ polymerization resulted in the hydrophilic nature and high permeation flux of the polymer after spinning and lowering of the pore size.

Further, enhancements in the flux were studied by Mufang et al. [32] using hydrophilic polyvinyl alcohol-co-ethylene. The membranes were used as filter media for many of the nanoparticles, e.g., 99\% of the nanoparticles were removed from the $\mathrm{TiO}_{2}$ suspension, and they exhibited high flux rates, and were superior to other MF membranes (Figure 1).

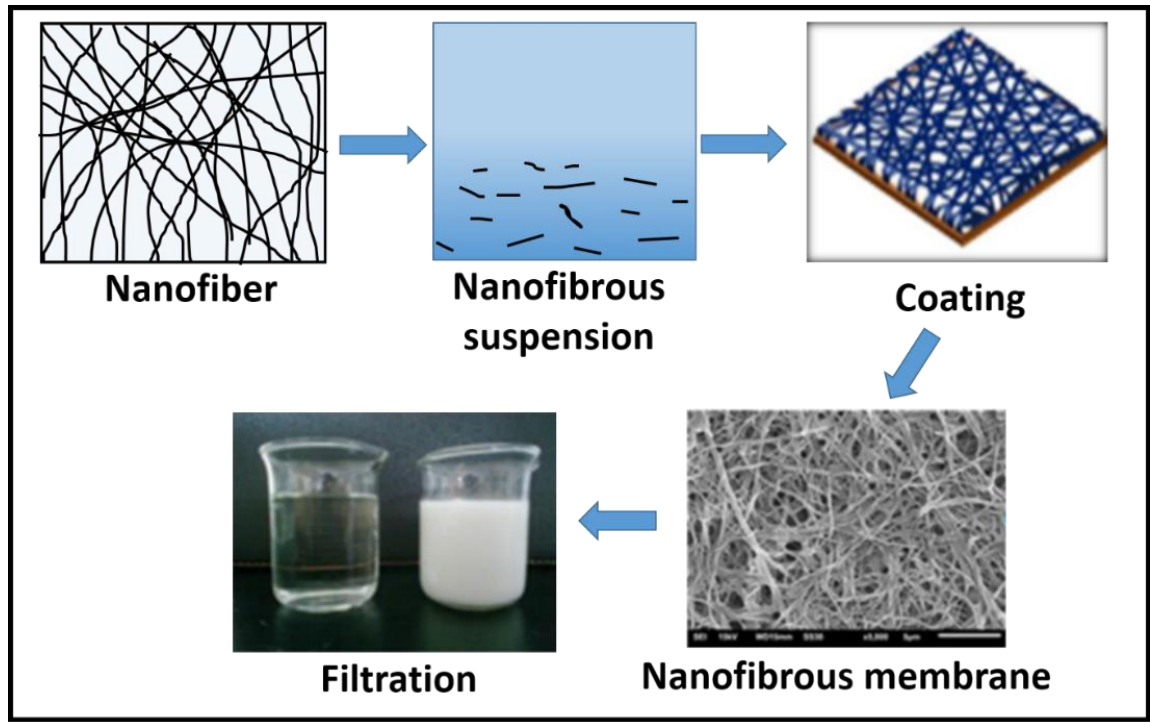

Figure 1. Nanofiber preparation and separation of the $\mathrm{TiO}_{2}$ suspension Adopted from Ref. [32]. 


\subsubsection{Heavy Metal Removal}

Heavy metal ions are one among the major threats to water resources, and many efforts has been made to eliminate toxic heavy metals from water. Adsorption, surface reactions, or catalytic reduction are a few possible methods that are used to remove toxic particles. For example, alumina and micellar-enhanced filtration (MEF) adsorption are used to remove $\mathrm{Cu}(\mathrm{II})$ ions in ground water [33]. Sodium dodecyl benzene sulfonate (SDS) micelles help with the electrostatic removal of cations. These micelles exhibit as secondary contamination when they are filtered through a chloridized polyvinyl chloride (PVC) nanofiber membrane. Alumina particles were employed to cure this problem, as the negatively charged micelles were attached to positively charged alumina particles, and they removed $100 \% \mathrm{Cu}(\mathrm{II})$ ions from groundwater. Chromium, a heavy metal that is highly toxic in water was studied by Jianqiang et al. [34]. In his study, an electrospinning method was applied to produce a polyacrylonitrile/polypyrrole (PAN/PPy) core/shell nanofiber sheet, and this was subjected to chemical oxidation. Selective adsorption of anions due to the interaction between PPy and heavy metal anions during adsorption was the key process for the model. An anion exchange process between $\mathrm{Cr}(\mathrm{VI})$ and $\mathrm{Cl}^{-}$, followed by a redox process with $\mathrm{Cr}(\mathrm{VI})$ ions, was detected. The adsorption relied on the time taken for protonation of the PAN/PPy nanofiber sheet and it increased with increase in protonation time. It showed good selectivity for $\mathrm{Cr}$ (VI) reduction to $\mathrm{Cr}$ (III), and other anions $\left(\mathrm{SO}_{4}{ }^{2-}, \mathrm{Cl}^{-}\right.$, and $\left.\mathrm{NO}^{3-}\right)$, except for $\mathrm{PO}_{4}{ }^{3-}$ which remained unaffected. Other heavy metal ions such as $\mathrm{Fe}(\mathrm{III}), \mathrm{Cd}(\mathrm{II})$, and $\mathrm{Cu}(\mathrm{II})$ were removed using amide oxime-modified PAN (AOPAN)/cellulose acetate (CA), via the electrospinning technique [35]. The saturation absorption of the nanofibrous membrane for these metal ions was found to be 7.47, 1.13, and $4.26 \mathrm{mmol} / \mathrm{g}$. Excellent reproducibility with over $80 \%$ adsorption and desorption capacities were observed with the modified membrane. A zeolitic imidazolate framework (ZIF-8)-coordinated electrospun nanofiber membrane was tested with heavy metal removal by Want et al. [36]. The property of a high surface area of the electrospun PAN membrane, along with properties of the microporous ZIF-8 material as active sites, supports the effective removal of heavy metals, resulting in a high permeation flux $\left(180 \mathrm{~L} / \mathrm{m}^{2} / \mathrm{h} / \mathrm{psi}\right)$. This comparison shows that the coordinated PAN membrane showed thrice the heavy metal removal capacity than the normal PAN membrane.

Aerogels formed by a quaternary ammonium-functionalized cellulose nanofiber was studied by $\mathrm{Xu}$ et al. [37] for Cr removal. A large surface area of fibers triggers the speedy and active rejection of $\mathrm{Cr}(\mathrm{VI})$ from contaminated water. Over $99 \%$ of $\mathrm{Cr}(\mathrm{VI})$ was removed in 50 min with $1 \mathrm{~g}$ of aerogel, in $1 \mathrm{~L}$ of $1 \mathrm{mg} / \mathrm{L}$ solution. Xiao et al. [38] reported a nanofiltration membrane formed via the phase inversion method, after cross-linking amines with $1 \%$ trimesoylchloride by interfacial polymerization (IP). The membrane had a smaller pore size, allowing the rejection of salt $(\mathrm{NaCl})$ from $74 \%$ (without IP) to $91 \%$ (with IP). Kyunghwan et al. [39] reported on electrospun PAN as a midlayer support in thin film nanocomposite (TFNC) membranes for nanofiltration. Different ratios of bipiperidine and piperazine formed the top polyamide barrier layer. Salt rejection $\left(\mathrm{MgSO}_{4}\right)$ was tested with these membranes, and it was found that the nanofiber membrane showed 2.4 times more flux than a thin-film composite membrane (TFC). Poly(methyl methacrylate) (PMMA) nanofibrous membranes doped with rhodanine (2-thioxo-4-thiazolidinone) were employed to remove heavy metals such as silver and lead [40]. The immobilization of carbazol-based Schiff base organic molecules into a polyvinyl alcohol (PVA)-tetraethyl orthosilicate (TEOS) inorganic polymeric support was reported by Arash et al. [41] to remove highly toxic mercury ( $\mathrm{Hg}(\mathrm{II}))$. The composite detects $\mathrm{Hg}$ (II) in the range of $0.020-0.50 \mathrm{ng} / \mathrm{mL}$, with a limit of detection (LOD) to $0.0180 \mathrm{ng} / \mathrm{mL}$ and a removal efficiency of 97-99\%. In another study, cysteine-modified polymer nanofibers were employed in Tannery waste water samples for the removal of $\mathrm{Cr}$ (III) [42]. At $\mathrm{pH} 5.5$, almost 99\% of $\mathrm{Cr}$ (III) was removed with only $0.1 \mathrm{mg}$ of nanofibers per mL of tannery waste water. About $1.75 \mathrm{~g} \mathrm{Cr} / \mathrm{g}$ of polymeric material was concluded to deliver the maximum removal capacity. A high surface-to-volume ratio, and large numbers of cysteine groups with binding affinities to heavy metals, are a significant cause of the high metal-removal capacity. Heavy metal ions such as $\mathrm{Cr}(\mathrm{VI}), \mathrm{Co}(\mathrm{III})$, and $\mathrm{Cu}(\mathrm{II})$ were efficiently 
removed with good stability and reproducibility, using a chitosan-based nanofiber membrane [43]. Modification of the chitosan surface as a rich amino-functionalized chitosan membrane by grafting of polyglycidyl methacrylate (PGMA) and polyethylenimine (PEI) effectively improves the removal ability of the ENM. The adsorption process follows a pseudo-second-order model with maximum adsorption capacities of 138.96, 68.31m and $69.27 \mathrm{mg} / \mathrm{g}$ respectively. Recently, polyaniline-grafted chitosan (PGC) was reported as a sorbent material for the removal of $\mathrm{Pb}$ (II) and $\mathrm{Cd}$ (II) ions. Monolayer Langmuir isotherm adsorption was recorded to be $16.07 \mathrm{mg} / \mathrm{g}$ and $14.33 \mathrm{mg} / \mathrm{g}$ for $\mathrm{Pb}$ (II) and Cd(II) ions, respectively [44]. Similarly, a surface-modified polytetrafluoroethylene (PTFE) membrane using a hyper-branched poly- amidoamine (HPAMAM) showed good efficiency towards the removal of $\mathrm{Cu}^{2+}$ ion. The water flux improved, and the rejection property was undisturbed when using the modified PTFE membrane. Pure PTFE showed $0 \mathrm{~L} / \mathrm{m}^{2} / \mathrm{hr}$ flux, whereas HPAMAM grafted PTFE membranes showed $635 \pm 9 \mathrm{~L} / \mathrm{m}^{2} / \mathrm{hr}$ flux. Approximately $1.42 \mathrm{~g} / \mathrm{m}^{2} \mathrm{Cu}^{2+}$ ions were adsorbed by the grafted polymer from an aqueous solution, with a desorption rate of $90 \%$ under index acidic conditions [45]. A few more reports on composite nanofiber mats are highlighted in Table 1.

Table 1. Composite nanofiber membranes for heavy metal removal.

\begin{tabular}{|c|c|c|c|c|c|}
\hline Nanofiber Material & Target Pollutant & Pollutant Removal Efficiency & Method & $\mathrm{pH}$ & Ref. \\
\hline Citric acid-modified acrylic fibers & $\mathrm{Cu}(\mathrm{II})$ and $\mathrm{Ni}(\mathrm{II})$ & $\begin{array}{l}\mathrm{Ni}(\mathrm{II})=2.55 \mathrm{mg} / \mathrm{g} \text { at } 250 \mathrm{mmol} / \mathrm{g} \\
\mathrm{Cu}(\mathrm{II})=2.56 \mathrm{mg} / \mathrm{g} \text { at } 250 \mathrm{mmol} / \mathrm{g}\end{array}$ & $\begin{array}{l}\text { Grafting, } \\
\text { Electrospinning }\end{array}$ & 6 & [46] \\
\hline Chitin nanofibrils & $\begin{array}{l}\mathrm{Pb}(\mathrm{II}) \\
\mathrm{Ni}(\mathrm{II}), \mathrm{Cd}(\mathrm{II}) \\
\mathrm{Cu}(\mathrm{II})\end{array}$ & $\begin{array}{l}303.49 \mathrm{mg} / \mathrm{g}, 134.72 \mathrm{mg} / \mathrm{g} \\
330.15 \mathrm{mg} / \mathrm{g}, 141.08 \mathrm{mg} / \mathrm{g}\end{array}$ & Mechanical defibrillation & 5 & [47] \\
\hline $\begin{array}{l}\text { Phosphorylated PAN-based nanofiber } \\
\text { (P-PAN) mat }\end{array}$ & $\begin{array}{l}\mathrm{Ag}(\mathrm{I}), \text { and } \mathrm{Cd}(\mathrm{II}) \\
\mathrm{Pb}(\mathrm{II}), \mathrm{Cu}(\mathrm{II})\end{array}$ & $\begin{array}{l}102.40 \mathrm{mg} / \mathrm{g} \text {, and } 18.89 \mathrm{mg} / \mathrm{g} \text {, } \\
98.06 \mathrm{mg} / \mathrm{g}, 78.03 \mathrm{mg} / \mathrm{g}\end{array}$ & $\begin{array}{l}\text { Electrospinning and } \\
\text { chemical modification }\end{array}$ & 6 & [49] \\
\hline $\begin{array}{l}\text { Silk Fibroin/cellulose } \\
\text { acetate-blend nanofibers }\end{array}$ & $\mathrm{Cu}(\mathrm{II})$ & $22.8 \mathrm{mg} / \mathrm{g}$ & Electrospinning & - & [50] \\
\hline $\begin{array}{l}\text { Cysteine-modified polypyrrole } \\
\text { propylic acid nanofibers }\end{array}$ & $\mathrm{Cr}(\mathrm{III})$ & $1.75 \mathrm{~g} \mathrm{Cr} / \mathrm{g}$ of polymer & $\begin{array}{c}\text { Electrochemical } \\
\text { template-directed } \\
\text { method }\end{array}$ & 3.28 & [42] \\
\hline $\begin{array}{l}\text { Iron oxide-alumina mixed } \\
\text { nanocomposite fibers using } \\
\text { Polyvinylpyrrolidone (PVP) }\end{array}$ & $\begin{array}{l}\mathrm{Ni}(\mathrm{II}), \mathrm{Hg}(\mathrm{II}) \\
\mathrm{Cu}(\mathrm{II}), \mathrm{Pb}(\mathrm{II})\end{array}$ & $\begin{array}{l}32.36 \mathrm{mg} / \mathrm{g}, 63.69 \mathrm{mg} / \mathrm{g}, \\
4.98 \mathrm{mg} / \mathrm{g}, 23.75 \mathrm{mg} / \mathrm{g}\end{array}$ & Electrospinning, Sol gel & 6 & [52] \\
\hline Sodium titanate nanofibers & $\begin{array}{l}\text { (a) } \mathrm{Ni}(\mathrm{II}), \mathrm{Zn}(\mathrm{II}) \text {, } \\
\mathrm{Cu}(\mathrm{II}) \text {, and } \mathrm{Cd}(\mathrm{II}) \\
\text { (b) } \mathrm{Pb}(\mathrm{II})\end{array}$ & $\begin{array}{l}\text { (a) } 60,83,115 \text {, and } 149 \mathrm{mg} / \mathrm{g} \\
\text { (b) } 250 \mathrm{mg} / \mathrm{g}\end{array}$ & Hydrothermal & $\begin{array}{l}\text { (a) } 6.5 \\
\text { (b) } 4\end{array}$ & [53] \\
\hline $\begin{array}{l}\text { Rhodanine and poly(methyl } \\
\text { methacrylate) }\end{array}$ & $\operatorname{Ag}(\mathrm{I})$ and $\mathrm{Pb}(\mathrm{II})$ & 140 and $115 \mathrm{mg} / \mathrm{m}^{2}$ & Electrospinning & - & [40] \\
\hline
\end{tabular}

\subsubsection{Antibacterial Activity}

Hongyang et al. [54] reported a MF membrane produced using surface-functionalized PAN nanofibers. The polymerization of dual- and tri-vinyl monomers on the surface of PAN nanofibers improved the membrane's mechanical strength, due to cross-linking. Efficient removal of bacteria and viruses were observed, with $99.99 \%$ retention of bacteriophages and $99.9999 \%$ retention of bacteria. Moreover, these membranes exerted high permeation flux and low rates of pressure drop. Doping of a poly(ether sulfone) (PES) ultrafiltration membrane comprising halloysite nanotubes with copper ions acts as a good anti-bacterial agent [55]. The modified membrane showed high hydrophilicity and high water flux. Antibacterial activity with E. coli and S. aureus were tested, and it shows excellent properties against these microorganisms.

Polylactic co-glycolic acid (PLGA), a biocompatible polymer nanofiber loaded with different concentrations of silver nanoparticles $(0,1,7 \mathrm{wt} \%)$ and evaluated for liver cancer cell lines. Increased 
concentrations of silver nanoparticles (Ag NPs) showed a remarkable improvement in polymer anticancer properties. PLGA nano-fibers with $1 \%$ of nanosilver loading showed $8.8 \%$ of anticancer activity, and by increasing the concentration to $7 \%$, the anticancer activity was enhanced to $67.6 \%$. Further, these nanofiber materials were extended to understand the antibacterial activities against five bacterial strains, namely; E. coli, S. aureus, Bacillus cereus, Listeria monocyte genes, and Salmonella typhimurium, by using the disc diffusion method, and they showed enhanced inhibitory effects. In the case of 7\% PLGA/AgNPs, the loaded sample inhibited all strains, whereas for only one strain (B. cereus), inhibition was observed for a $1 \%$ PLGA/AgNP-loaded nanofiber membrane [56]. The characteristics of the filter mat showed excellent behavior when composites such as silver-infused $\mathrm{TiO}_{2} /$ nylon- 6 were involved [57]. Silver or AgNPs were photocatalytically reduced under UV irradiation in $\mathrm{TiO}_{2} /$ nylon 6 nanofiber mats. Spider wave-like structures caused by $\mathrm{TiO}_{2} \mathrm{NPs}$ in the nylon 6 solution facilitated the reduction of $\mathrm{AgNO}_{3}$ to $\mathrm{Ag}$, and the mats exhibited good antibacterial activity against $E$. coli. The reuse of nanoparticles will make the material an economically friendly catalyst and filter media.

The colonization of bacteria on titanium-implanted Sprague-Dawley rats was examined by Samuel et al. [58], using antibacterial nanofiber membranes. Nanofiber membranes loaded with drugs such as biocides (fusidic acid and rifampicin) were implanted onto the titanium surface. Upon injection, S. aureus the antibacterial nanofiber membranes prevented the adhesion of bacteria onto the implanted site. Similarly, Daels et al. [59] calculated the antibacterial properties of polyamide membranes loaded with five different biocides, to treat hospital waste water. About $4.0 \log _{10}$ reductions of bacterial numbers were observed for drug-loaded membranes, which was higher than the control $\left(5.2 \log _{10}\right.$ reduction). Another report on surface-modified nanofiber membranes, showing highly effective antibacterial activity against E. coli and S. aureus activity, was reported by Chen et al. [60]. Plasma pretreatment, UV-induced grafting of 4-vinylpyridine, followed by the quarternization of grafted pyridine groups was conducted on polyurethane nanofiber membranes. Poly(hexamethylene guinidine hydrochloride) (PHGH) was attached to flexible spacers, which extended from amino groups from the reduced nitrile groups on PAN nanofibers, were produced to study the antibacterial activity against $S$. aureus and E. coli. The surface-modified nanofiber mats showed ease of cleaning, due to the hydrophilic spacers, and high antibacterial activity, even after a few cycles of antibacterial assays [61].

\subsubsection{Dye Removal}

Functional group-modified PAN using sodium hydroxide and bicarbonate act as a sorbent for malachite green (MG) and cationic dyes. A modified PAN membrane removed 99\% of MG, with an adsorption capacity of $200 \mathrm{mg} / \mathrm{g}$ (five times higher than non-functionalized PAN) [62]. Composite nanofibers made of PAN-polyamidoamine (PAMAM) were synthesized and investigated with Direct Red 23 dyes and Direct Red 80, with a dye adsorption capacity amounting to $2000 \mathrm{mg} / \mathrm{g}$ and $1666.66 \mathrm{mg} / \mathrm{g}$, respectively. The increase in dye adsorption was due to higher loading of the active polymer, which created more active sites for dye adsorption on the surfaces of the fibers [63]. A PVA/CA composite was reported for the removal of MG, by Xiaoli et al. [64]. The foam exhibits well-interconnected pores and good mass transfer properties, and it removes dye even at very low concentration $(<100 \mathrm{mg} / \mathrm{L})$, and it is reusable. A membrane filter made from nylon-6 nanofibers on a carbon-coated polyurethane substrate was tested by using C.I. Direct yellow 12. A filtration efficiency of $98 \%$ was achieved in $150 \mathrm{ppm}$ of coagulant material at 0.75 bar pressure [65]. The application of a fast molecular filtration method, was reported to remove the hydrophilic dyes using poly(ether amine) (PEA) nanofiber membranes. UV dimerization of the coumarin groups were cross-linked to the PEA membrane for adsorption studies. Strong adsorption with Ponceau S (PS), Ponceau SX (PSX), Orange G (OG), Rose Bengal (RB), and Bismarck brown Y (BY), were observed, and weak adsorption to rhodamine 6G (R6G) and Methylene Blue trihydrate (MB), was reported. These membranes also separate mixtures of PS/MB in aqueous solution through molecular filtration, with a very high flux rate of $2870 \mathrm{~L} / \mathrm{m}^{2} / \mathrm{hr}$ [66]. Another composite nanofibrous filter medium of polyamide $6 /$ chitosan was fabricated onto a satin fabric substrate by electrospinning. Polar Yellow GN and Solophenyl Red 3BL, 
and acidic and direct dyes were investigated at different $\mathrm{pH}$ levels and initial dye concentrations, along with different membrane parameters. A 95\% removal rate of Polar Yellow GN, and a 96\% removal rate of Solophenyl Red 3BL was observed when using these mixed nanofiber membranes [67].

Nanoparticle-loaded nanofiber membranes also exhibit good dye-removing capabilities. For example, AgNPs loaded on electrospun $\mathrm{TiO}_{2}$ nanofibers for dye degradation were studied by Lei et al. [68]. Under solar irradiation, the $\mathrm{Ag} / \mathrm{TiO}_{2}$ nanofiber membrane achieved $80 \%$ dye degradation under within $30 \mathrm{~min}$, due to high permeate flux when compared to a commercial P25 membrane. Similarly, an organically modified montmorillonite composite with PAN membrane coated with $\mathrm{TiO}_{2}$ improved the adsorption of methylene blue (MB) [69]. Another report on the removal of MB was documented by Aluigi et al. [70] by using a keratin nanofibrous membrane (dia. $220 \mathrm{~nm}$ ), according to batch adsorption tests. Functionalized PES nanofibrous membranes were synthesized by $\mathrm{Xu}$ et al. by blending PES with a copolymer of acrylic acid and methyl acrylate [71]. High porosity, large specific area, and abundant carboxyl groups showed the largest adsorption capacity, removing $2257.88 \mathrm{mg} / \mathrm{g}$ of methylene blue dyes. Its recyclability of up to five cycles, with a competence of $81.5 \%$, a purification efficiency of $>99 \%$ and at a high flux of $100 \mathrm{~mL} / \mathrm{min}$ are other key promising properties. Poly (L-lactic acid) (PLLA) nanofibrous adsorbents produced through air plasma etching treatment effectively removed Methylene Blue dye via electrostatic interaction. The presence of active binding sites after plasma etching, and the high surface area of the membrane were factors contributing to its performance. Its adsorption kinetics fit well with a pseudo-second-order model, revealing a monolayer for chemical adsorption, and it also exhibited good recycling efficiency [72]. Hydrolysis of a polymer of intrinsic microporosity (PIM-1) by $65 \%$ to $99 \%$, with a fiber diameter ranging from 0.58 to $1.21 \mu \mathrm{m}$, showed extensively high performance in the removal of organic dyes from the wastewater [73]. With the concertation of $20 \mathrm{mg} / \mathrm{L}$ dye solution, PIM-1 nanofibers exhibited a removal efficiency of about $157 \mathrm{mg} / \mathrm{g}$ for Methylene Blue, with a maximum dye removal efficiency of $272 \mathrm{mg} / \mathrm{g}$, and also of $4 \mathrm{mg} / \mathrm{g}$ for Congo Red. The modification of PAN nanofibers with chelating agents such as ethylenediaminetetraacetic acid (EDTA) and ethylenediamine (EDA) changed the distribution of nanofibers, resulting in reduced softness but with no effect on the structure. Their efficient sorption of Methyl Orange (MO) and Reactive Red (RR) showed maximum absorption capacities of $99.15 \mathrm{mg} / \mathrm{g}$ and $110 \mathrm{mg} / \mathrm{g}$, respectively [74].

\subsection{Metal Oxides as Pollutant Removal Media}

The macroscopic properties of metal oxides vary with the intrinsic insertion of nano-sized particles. These nanostructures enhance many properties of the individual particles, which could lead to major applications in many desired fields. Particles with defined shapes, and uniform domains and morphologies possess unique properties, which differ from their macroscopic properties. Many such nano-metal oxides have been discussed under these topics, for the effective removal of heavy metals and dyes, and as materials for the study of antibacterial activity against bacteria and viruses.

\subsubsection{Heavy Metal Removal}

Various techniques have been employed to deal with the removal of heavy metals-chemical precipitation, adsorption, and electrochemical methods. In most of these techniques, the adsorption method is the most logical and easiest method for removal studies. Although many techniques are available, it is the material that matters in the efficient removal of pollutants. Macro- to nano-sized materials play a predominant role in the efficiency of heavy metal removal. Jianming et al. [75] reported core shell-nanostructured $\mathrm{Fe}_{3} \mathrm{O}_{4} @ \mathrm{SiO}_{2}-\mathrm{NH}_{2}$ nanoparticles for the effective removal of toxic $\mathrm{Pb}$ (II) metals $\left(\mathrm{QM}=243.9 \mathrm{mg} / \mathrm{g}\right.$ at $\left.25^{\circ} \mathrm{C}\right)$ in which the presence of amine functional groups on the surface is responsible for the majority of the removal mechanism. Mesoporous magnetite nanospheres synthesized using a solvothermal method were reported by Madhu et al. [76]. Their adsorption at mild acidic $\mathrm{pH}$ values and at different temperatures enabled the selective removal of $\mathrm{Cr}^{6+}$ and $\mathrm{Pb}^{2+}$ effectively, and this fitted well with pseudo-second-order kinetics. The Langmuir adsorption capacities 
were 19 and $9 \mathrm{mg} / \mathrm{g}$ for $\mathrm{Pb}^{2+}$ and $\mathrm{Cr}^{6+}$, respectively, and the spheres were reusable after further isolation (Scheme 1).

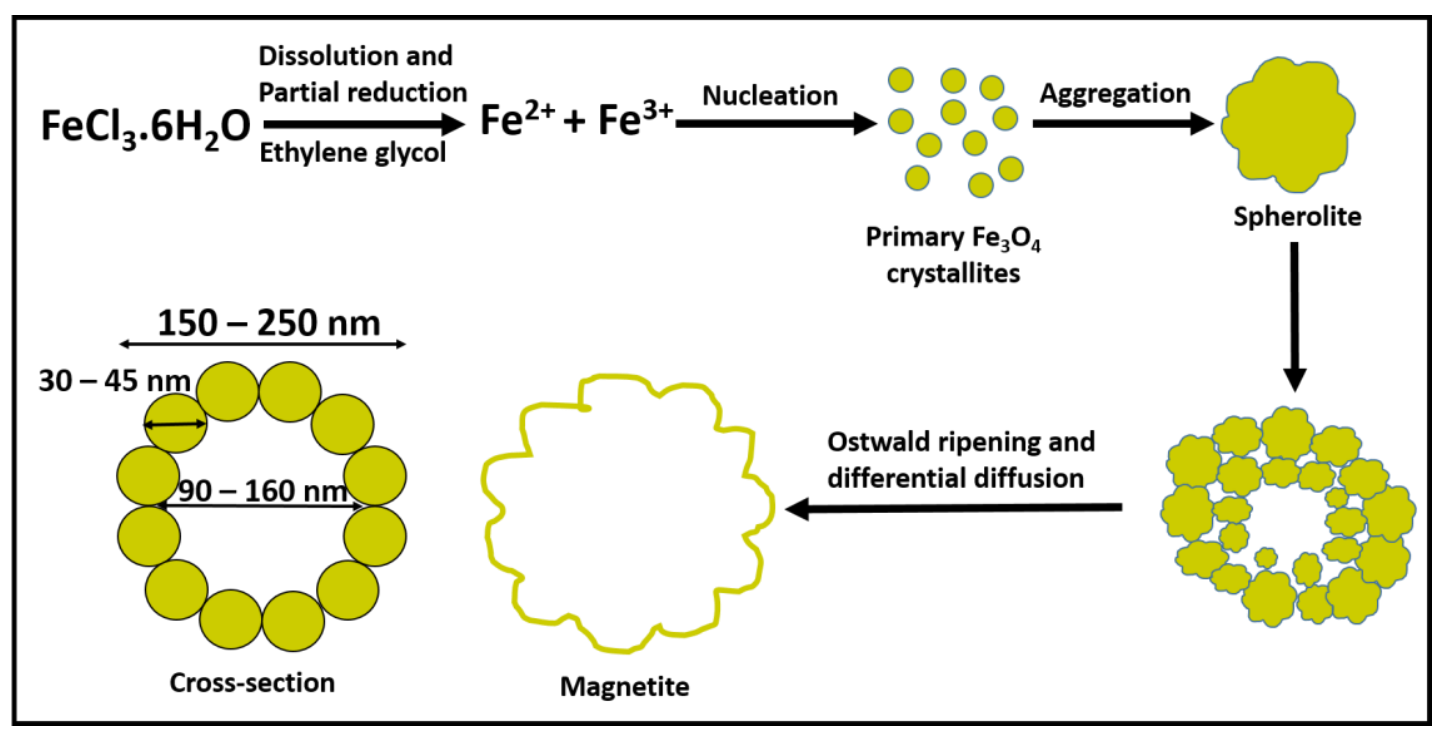

Scheme 1. Schematic of magnetite nanosphere formation and evolution. Adopted from Ref. [76].

Similarly, $\gamma-\mathrm{Fe}_{2} \mathrm{O}_{3}$ (maghemite) nanoparticles were employed by Ali et al. [77] for the selective removal of toxic metal ions such as $\mathrm{Zn}(\mathrm{II}), \mathrm{Pb}(\mathrm{II})$, and $\mathrm{Cd}(\mathrm{II})$. The observed selectivity order for removal was $\mathrm{Zn}$ (II) $4.79 \mathrm{mg} / \mathrm{g}$, $\mathrm{Pb}$ (II) $10.55 \mathrm{mg} / \mathrm{g}$, and Cd(II) $1.75 \mathrm{mg} / \mathrm{g}$, showing that Pb-Zn waste waters can be decontaminated effectively by using $\gamma-\mathrm{Fe}_{2} \mathrm{O}_{3}$. Surface-modified $\mathrm{Fe}_{3} \mathrm{O}_{4}$ nanoparticles embedded in silica were mixed with a PES membrane for $\mathrm{Cu}(\mathrm{II})$. Due to the improved hydrophilicity and the nucleophilic functional groups on the nanoparticles, the copper removal capability increased remarkably [78].

Bimetallic nanoparticles made of $\mathrm{Fe} / \mathrm{Ni}$ reinforced by kaolinite $(\mathrm{K}-\mathrm{Fe} / \mathrm{Ni})$ were used to target $\mathrm{Cu}(\mathrm{II})$ and nitrate ions. The removal of both metals and anions were mutually affected when using $\mathrm{K}-\mathrm{Fe} / \mathrm{Ni}$. A total of $42.5 \%$ of nitrate was degraded when $\mathrm{Cu}(\mathrm{II})$ was present, and if $\mathrm{Cu}$ (II) was reduced to $\mathrm{Cu}^{0}$ onto the surface of kaolinite-supported $\mathrm{Fe} / \mathrm{Ni}$, it forms a new catalyst, $\mathrm{K}-\mathrm{Fe} / \mathrm{Ni} / \mathrm{Cu}[79]$. For Modified sewage sludge using $\mathrm{Fe}_{2} \mathrm{O}_{3}$ containing a high surface area, the pore volume was applied for the removal of ions such as $\mathrm{Ni}(\mathrm{II}), \mathrm{Cu}(\mathrm{II}), \mathrm{Pb}(\mathrm{II})$, and $\mathrm{Cd}(\mathrm{II})$ [80], and the maximum adsorption was exhibited to be 7.8, 17.3, 14.7, and $42.4 \mathrm{mg} / \mathrm{g}$, respectively, at neutral pH. 3-dimensional organized mesoporous silica (OMS) coated with $\mathrm{Fe}_{2} \mathrm{O}_{3}$ and $\mathrm{Al}_{2} \mathrm{O}_{3}$ was channeled for $\mathrm{As}$ (III) and As(V) removal [81]. An 8\% metal-coated sample showed optimal conditions for removal efficiency.

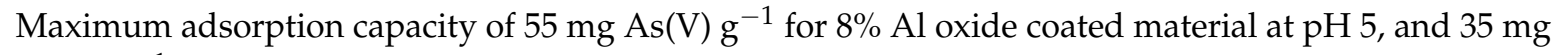
$\mathrm{As}(\mathrm{V}) \mathrm{g}^{-1}$ for iron oxide-coated material at $\mathrm{pH} 4$ was reported.

\subsubsection{Dye Removal using Metal Oxide as a Sorbent}

$\mathrm{Fe}_{3} \mathrm{O}_{4}$ loaded with Fe nanoparticles was analyzed for its capability to remove methyl red (MR). It exhibits an excellent absorption of $625 \mathrm{mg} / \mathrm{g}$, which was higher when compared to previously reported zeolite and activated carbon [82]. Hierarchical porous iron oxides produced by a thermal conversion method was proven to be more effective towards Congo red dye. The Langmuir constants for $\mathrm{Fe}_{3} \mathrm{O}_{4}, \alpha-\mathrm{Fe}_{2} \mathrm{O}_{3}$, and $\gamma-\mathrm{Fe}_{2} \mathrm{O}_{3}$ were found to be $84.96 \mathrm{mg} / \mathrm{g}, 139.86 \mathrm{mg} / \mathrm{g}$, and $69.35 \mathrm{mg} / \mathrm{g}$ respectively, indicating adsorbent behavior of iron oxide superstructures [83].

$\mathrm{Fe}_{2} \mathrm{O}_{3}-\mathrm{Al}_{2} \mathrm{O}_{3}$ nanocomposites have a good adsorbent property towards Congo red. The removal capacity for $\gamma \mathrm{Fe}_{2} \mathrm{O}_{3}-\mathrm{Al}_{2} \mathrm{O}_{3}$ phase was recorded as $498 \mathrm{mg} / \mathrm{g}$. Among the three different phase oxides, $\gamma$-phase acts as a good adsorbent, with 100\% removal of Congo red in a 15 min saturation time [84]. Other mixed metal oxides for the removal of malachite green oxalate dye were reported by 
Kumar et al. [85], using $\mathrm{ZnO}$ and $\mathrm{SiO}_{2}$. The maximum removal rate of Malachite green Oxalate (MGO) was $144.5 \mathrm{mg} / \mathrm{g}$ with $\mathrm{ZnO}$, and $149.03 \mathrm{mg} / \mathrm{g}$ with $\mathrm{SnO}_{2}$. Further studies on dye removal have been tabulated in Table 2.

Table 2. Metal oxides in dye degradation and/or removal.

\begin{tabular}{|c|c|c|c|c|c|}
\hline S. No & Metal Oxide & Target Dye & $\begin{array}{l}\text { Removal } \\
\text { Efficiency }\end{array}$ & $\mathrm{pH}$ & References \\
\hline 1 & $\begin{array}{l}\text { Cobalt }(\mathrm{Co}) \text { and nickel } \\
(\mathrm{Ni}) \text { oxide } \\
\left(\mathrm{Co}_{0.4} \mathrm{Ni}_{0.4} \mathrm{O}_{0.2}\right)\end{array}$ & $\begin{array}{l}\text { Methylene blue (MB) } \\
\text { and Procion red (PR) }\end{array}$ & $\begin{array}{l}\mathrm{MB}-20 \% \\
\mathrm{PR}-70 \%\end{array}$ & 9.5 & [86] \\
\hline 2 & $\begin{array}{l}\text { Pectin-thorium (IV) } \\
\text { tungstomolybdate } \\
\text { (Pc/TWM) }\end{array}$ & Methylene Blue & $76 \%$ & - & [87] \\
\hline 3 & $\begin{array}{c}\text { Horseradish } \\
\text { peroxidase (HRP) was } \\
\text { encapsulated in } \\
\text { phospholipid-template } \\
\text { titania particles }\end{array}$ & Direct Black-38 & $79.72 \%$ & $6-9$ & [88] \\
\hline 4 & $\begin{array}{c}\mathrm{Fe}_{3} \mathrm{O}_{4}-\mathrm{ZnO} \text { magnetic } \\
\text { semiconductor } \\
\text { nanocomposite }\end{array}$ & $\begin{array}{l}\text { Methylene Blue, } \\
\text { Methyl Orange, } \\
\text { Rhodamine B }\end{array}$ & - & $\begin{array}{l}\text { Photo } \\
\text { degradation }\end{array}$ & [89] \\
\hline 5 & $\begin{array}{c}\text { Magnetic } \\
\mathrm{Fe}_{3} \mathrm{O}_{4} / \mathrm{ZnCr}-\mathrm{LDH} \\
\text { (Layered double } \\
\text { hydroxide) }\end{array}$ & Methyl Orange (MO) & $81.23 \%$ & $6.4-7.3$ & [90] \\
\hline 6. & $\begin{array}{c}\mathrm{BiFeO}_{3} / \mathrm{a}-\mathrm{Fe}_{2} \mathrm{O}_{3} \\
\text { core/shell composite }\end{array}$ & $\mathrm{MO}$ & $80 \%$ & 5.2 & [91] \\
\hline 7 & $\begin{array}{l}\text { Fe-Al binary } \\
\text { oxide }(5: 5)\end{array}$ & $\mathrm{AB} 25, \mathrm{AO} 7, \mathrm{MB}$ & $100 \%, 98 \%, 88 \%$ & - & [92] \\
\hline 8 & Chromium spheres & Congo Red & $75 \%$ & - & [93] \\
\hline
\end{tabular}

\subsubsection{Metal Oxide Nanomaterials with Antibacterial Activity}

An ideal disinfectant to tackle such pathogens should exhibit the following properties, as mentioned by Rutala et al. [94]: (a) Broad antibacterial ability at an ambient temperature over a short period of time, (b) no destructive by-products during and after use, (c) the disinfectant itself should not harm health, (d) economical and has easy applicability, and (e) easy storage, is water soluble, and has safe disposal.

Metal oxides generally execute ideal behaviors as disinfectants. For example [95], Zn/Fe oxide composite nanoparticles as mixed phases of zinc oxide, iron oxide and ferrite phases were tested for their antibacterial activity against $E$. coli and $S$. aureus, where this property depends mainly on the ratio of $[\mathrm{Zn} / \mathrm{Fe}]$. When the ratio of the composite was higher, it resulted in better antibacterial properties. Shape-dependent antibacterial effects were observed by Antony et al. [96], where differently shaped copper oxide $(\mathrm{CuO})$ nanomaterials were synthesized by simple sol-gel and hydrothermal approaches, and applied towards Gram positive and Gram negative bacteria. Among the differently shaped $\mathrm{CuO}$ crystals, plate-like morphologies showed more effective antibacterial activity than needle or grain shaped morphologies. Similarly, deposits of $\mathrm{CuO}$ on cellulose paper, commercial textiles, and poly(ether sulfone) (PES) flat sheets were studied by Booshehri et al. [97]. The main reason for the excellent behavior was due to the release of copper ions from the nanoparticles, and they could be considered as cheap materials to remove pathogens. Metal oxides such as $\mathrm{ZnO}, \mathrm{Cu}_{2} \mathrm{O}$, and $\mathrm{NiO}$ supported on natural clinoptilolite were investigated by Jasna et al. [98]. Among the nanoparticles, $\mathrm{Cu}_{2} \mathrm{O}$ and $\mathrm{ZnO}$ showed $100 \%$ reliability for antibacterial activity against S. aureus and E. coli, whereas 
$\mathrm{NiO}$ showed a lower affinity towards bacteria. Mixed oxides such as strontium titanate ferrite (STF) were also tested for their antibacterial activity by Zhang et al. [99]. Excellent bactericidal effects were observed against $E$. coli $\left(\mathrm{NiO}_{5} \mathrm{CFU} / \mathrm{mL}\right)$ over $15 \mathrm{~min}$ in both dark and light conditions, with the reason for this being $\mathrm{Sr}^{2+}$ dissociation and the possible contribution of the nanosized properties of $\mathrm{STF}_{0.8}$ metal.

\subsection{Carbonaceous Materials as Pollutant Removal Media}

Current trends in purification and separation techniques involve carbon-based materials for many major applications. The surface energy and area, conductivity, thermal stability, and mechanical stability are some of the key factors that enable carbon materials to be dopants or fillers, along with metals or polymers. Enhanced performance was observed with all of the materials when they were coupled with carbonaceous compounds.

\subsubsection{Heavy Metal Removal}

Magnetic graphene oxide ( $\left.\mathrm{MGO}-\mathrm{Fe}_{3} \mathrm{O}_{4}-\mathrm{GO}\right)$ functionalized with xanthate exhibits ideal behavior as an adsorbent for the removal of $\mathrm{Hg}$ (II) with a high capacity of $118.55 \mathrm{mg} / \mathrm{g}$ for $\mathrm{Hg}^{2+}$ in $180 \mathrm{~mm}$ at neutral $\mathrm{pH}$. Thermodynamic results indicated that adsorption was an endothermic and spontaneous process. The Major reason for the high selectivity was due to the specific surface area of graphene and the active xanthate groups [100]. Reduced graphene oxide (RGO)-metal/metal oxide, e.g., $\mathrm{MnO}_{2} / \mathrm{Ag}$ were prepared by simple synthetic methods by Sreeprasad et al. [101], and tested for the removal of $\mathrm{Hg}$ (II). Walnut shell-derived activated carbon (AC) was studied in an attempt to remove $\mathrm{Hg}$ (II) from industrial liquid streams [102]. AC has shown about $0.45 \mathrm{~g} / \mathrm{cm}^{3}$ density, $737 \mathrm{mg} / \mathrm{g}$ iodine, and $780 \mathrm{~m}^{2} / \mathrm{g}$ Brunauer-Emmett-Teller (BET) surface area as its material property, with a decrease in $\mathrm{Hg}$ (II) uptake with an increase in pH. A magnetic graphene oxide (MGO), synthesized by Jin et al., showed a maximum sorption up to $91.29 \mathrm{mg} / \mathrm{g}$ in a Cd(II) methylene blue binary system. Tap water samples showed a sorption capacity of $65.39 \%$ Cd(II) [103]. Functionalized MGO composites were employed in the removal of selenium ions, which are toxic at concentrations $>40 \mathrm{ppb}(40 \mu \mathrm{g} / \mathrm{L})$ (Scheme 2). The presence of MGO (1 g/L) demonstrated a removal efficiency of $80 \%$ for Se(VI), and $>99.9 \%$ for Se(IV) from water at neutral $\mathrm{pH}[104]$.

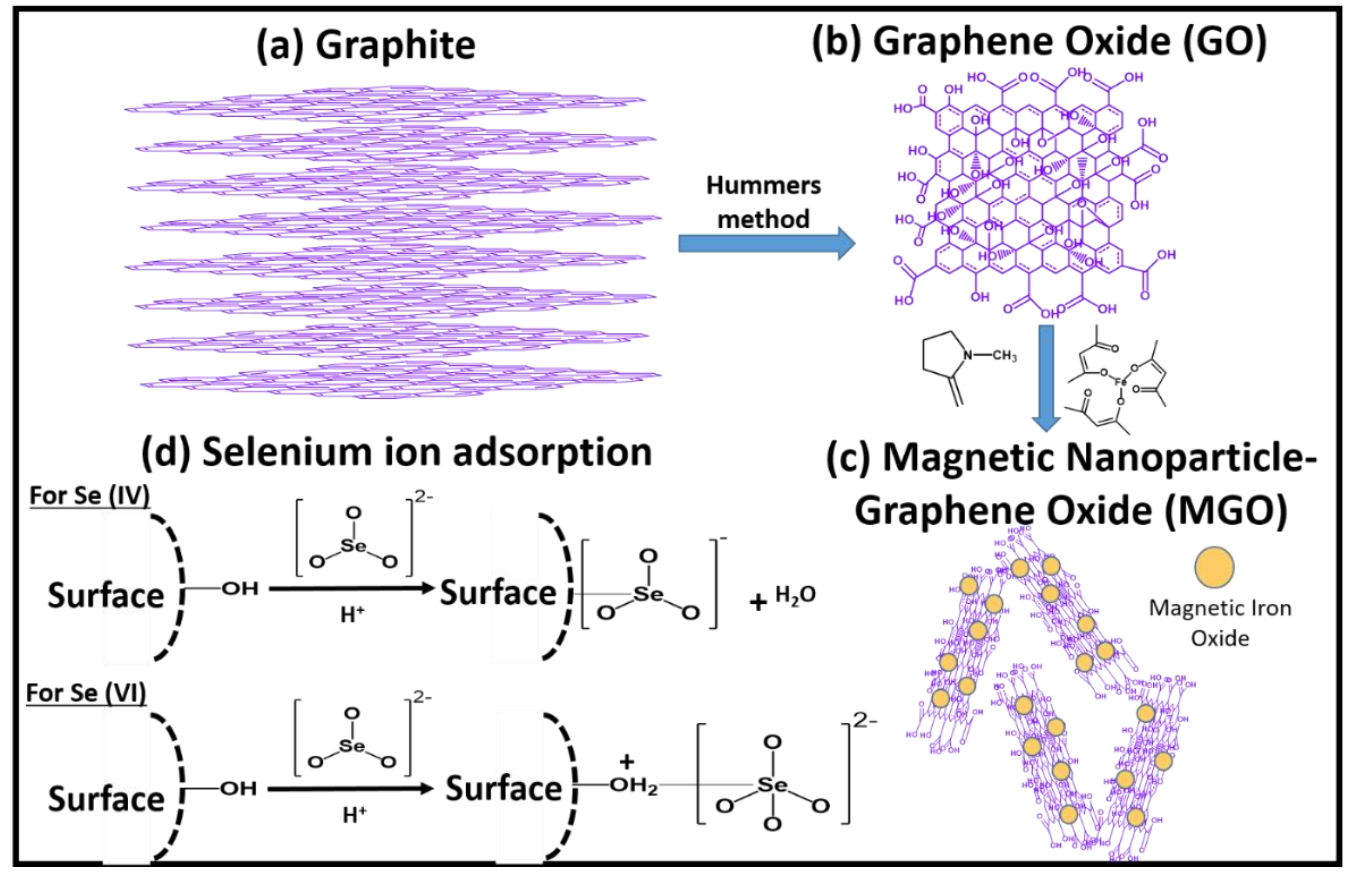

Scheme 2. The synthesis of magnetic iron oxide-graphene oxide (MGO). Adopted from Ref. [104]. 
Activated carbon (AC) after chemical and biological treatments (reduced active carbon by sodium sulphite, and modified by baker's yeast) was studied for the removal of cadmium. The highest sorption capacity was calculated to be $265 \mu \mathrm{mol} / \mathrm{g}$. A multistage column technique was applied with AC, and it showed a superior rate of cadmium metal recovery [105]. Similarly, silica/AC (2:3) composites exhibited further enhancements when compared to the individual silica material [106].

Surface-treated hydrogen-exfoliated graphene sheets with nitric acid produce hydrophilic functional groups, which activate arsenic (III) \& (V) removal quite effectively. The desalination of water, and the removal of sodium, arsenic, and arsenate with a maximum adsorption capacity of 122, 139, and $142 \mathrm{mg} / \mathrm{g}$, were obtained [107]. Other composites such as carbonaceous sulfur-containing chitosan, $\mathrm{Fe}$ (III) composites were developed to study the removal of $\mathrm{Cu}^{2+}$ from waste water. The majority of sulfur binds with Fe and forms a stable matrix with macropores, which help with trapping most of the $\mathrm{Cu}^{2+}$ ions. The $\mathrm{Cu}^{2+}$ adsorption was supported by chelation with oxygen moieties and with some sulfur atoms. An adsorption capacity of $413.2 \mathrm{mg} / \mathrm{g}$ for $\mathrm{Cu}^{2+}$ was observed over $2.5 \mathrm{~min}$, which is considered to be higher than all of the earlier reports for $\mathrm{Cu}^{2+}$ removal [108].

Graphene magnetic material $\left(\mathrm{Fe}_{3} \mathrm{O}_{4}-\mathrm{GS}\right)$ combinations prepared by Guo et al. [109] showed sorption capacities at $17.29(\mathrm{Cr}(\mathrm{VI})), 27.95(\mathrm{~Pb}(\mathrm{II})), 23.03(\mathrm{Hg}(\mathrm{II})), 27.83(\mathrm{Cd}(\mathrm{II}))$, and $22.0 \mathrm{mg} / \mathrm{g}(\mathrm{Ni}(\mathrm{II}))$ at a $\mathrm{pH}$ range of 3.5. Chelation and ion exchange mechanisms were involved in this removal process. Sand coated with sugar molecules followed by thermal heating for graphitization was reported by Renu et al. [110] for the removal of hexavalent chromium ions (Scheme 3). The increased specific area before and after carbonization helped with the remove $\mathrm{Cr}(\mathrm{VI})$ efficiently, and it was found to be $2859.38 \mathrm{mg} / \mathrm{g}$ at room temperature, which so far, is an exceptionally high reported value.

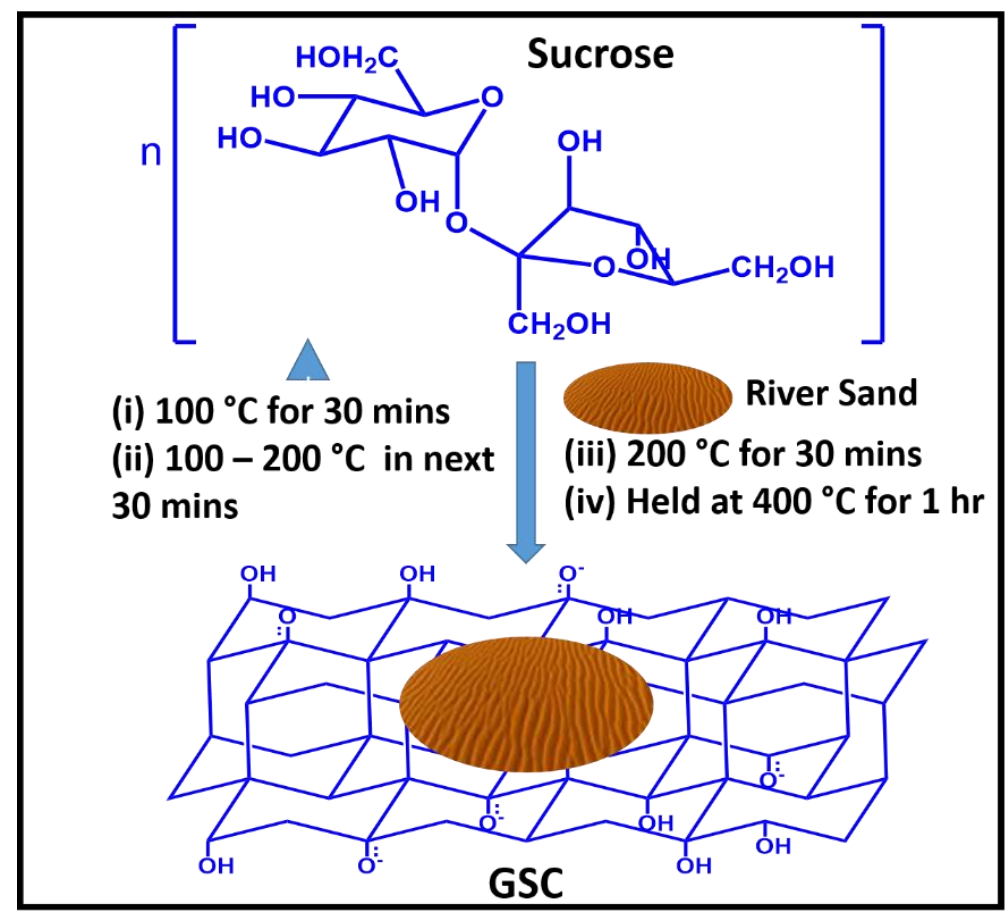

Scheme 3. Synthesis of sugar-coated sand. Adopted from Ref. [110].

Nano-hybrids of magnetic ferrite with graphene oxide nanoparticles has shown adsorption properties for $\mathrm{Pb}(\mathrm{II}), \mathrm{As}(\mathrm{III})$, and $\mathrm{As}(\mathrm{V})$. 3D graphene composites showed enhanced properties with the removal of metal ions. So far, many articles were reported on a 3D graphene oxide composite. The synthesis of 3D graphene oxide (GO) hydrogels containing nanoscale-layered double hydroxide (LDH) was reported by Qle et al. [111]. LDH acts as a crosslinking agent between GO nanosheets, and it forms a 3D network, and has been applied for the removal of $\mathrm{Cd}^{2+}$ from water with high capability. The major reason for its high capability is due to its hydrophilicity and stability, and the availability 
of its active sites in aqueous solution. Similarly, a poly(3-amino propyl triethoxysilane) oligomer cross-linked graphene oxide was synthesized by Shenglian et al. [112]. The adsorption capacity of $\mathrm{Pb}$ (II) was tested using this 3D network, and it showed an adsorption capacity of $312.5 \mathrm{mg} / \mathrm{g}$ at $303 \mathrm{~K}$; the adsorption further increased with increasing temperature. The material showed capability to remove $\mathrm{Pb}, \mathrm{Cu}$, and Fe from mixed solutions of metal ions. A direct 3D graphene foam prepared by Yinlin et al. was tested against different metal ions like $\mathrm{Zn}^{2+}, \mathrm{Fe}^{3+}, \mathrm{Pb}^{2+}$, and $\mathrm{Cd}^{2+}$, where the presence of high surface area and oxygen content helps in the efficient removal of the metal ions [113].

\subsubsection{Dye Removal}

Though polymer materials and metal oxides play a catalytic role in degrading or filtering dye materials, the quenching of highly efficient materials is always anticipated. Carbon-containing mixtures or mixed oxides with carbon are shown to be promising materials for addressing the above issues, to contain the extent of acceptability.

GO, upon its functionalization with various polymer or organic moieties, opens an extended window for the removal of dye particles. Cui et al. [100] reported a xanthate-functionalized magnetic graphene oxide $\left(\mathrm{Fe}_{3} \mathrm{O}_{4}-\mathrm{xGO}\right)$ in which the $\mathrm{MGO}$ removed methylene blue in $120 \mathrm{~min}$ at $\mathrm{pH} 5$ in a range of $526.32 \mathrm{mg} / \mathrm{g}$, with a good correlation of kinetics. The major reason for this maximum removal was due to chelation or ion exchange process. Acid yellow dye was tested with $\mathrm{AC}-\mathrm{Fe}_{3} \mathrm{O}_{4}$ at $\mathrm{pH} 5$ [114]. Chitosan cross-linked to graphite oxide were tested for black 5 dye, and exhibited a capacity of $277 \mathrm{mg} / \mathrm{g}$ at $25^{\circ} \mathrm{C}$. This higher removal capacity was due to ionic interaction/forces between the dye and composite. Similarly, rhamnolipid-functionalized GO by an ultra-sonication method was synthesized by $\mathrm{Wu}$ et al. [115]. The mesoporous and functional groups enhances the removal of MB dye with maximum capability (Scheme 4). Through, electrostatic attraction, $\pi-\pi$ interactions, and hydrogen bond. MB was further removed in an efficient way by a filtration technique. For example, Robert et al. [116] reported carbon nanofiber for elimination of MB. A high flux $\left(1580 \mathrm{~L} / \mathrm{m}^{2} / \mathrm{hr}\right) \mathrm{was}$ reported, which was 10-100 times higher than commercial nano or ultra-filtration membranes. These values were much higher in comparison to carbon nanotubes and granular active carbon. A large surface area, uniformity, and numerous active sites support the enhancement of MB dye adsorption.

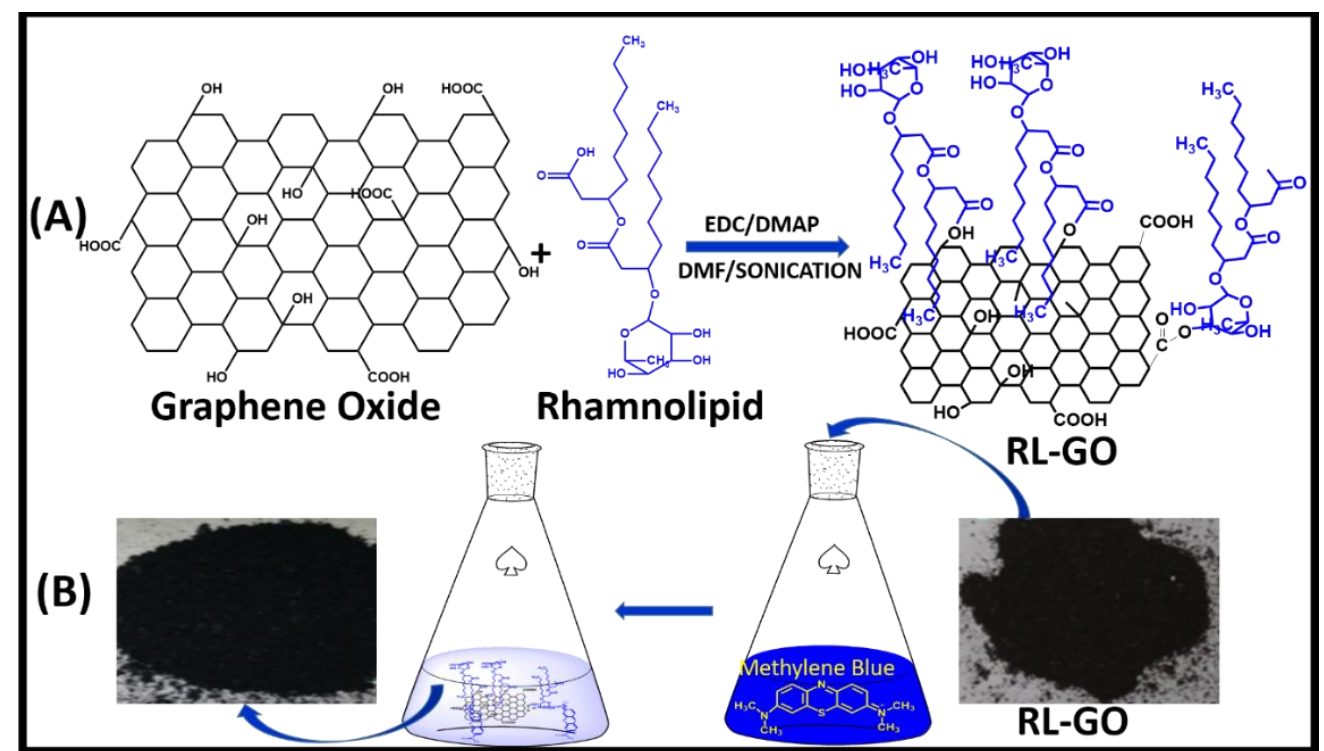

Scheme 4. Schematic depiction of the formation of rhamnolipid-functionalized graphene oxide (RL-GO), and its application for the removal of MB. Adopted from Ref. [115]. (A) Chemical reaction occurred between GO and RL; (B) Pictorial representation of the products. 


\subsubsection{Anti-Bacterial Activity}

Metal oxide-doped graphene systems exhibit a vast range of anti-bacterial activity. GO was decorated with Ag nanoparticles to form GO-Ag nanocomposites were tested for its antibacterial activity. Ag is well-known for its activity with bacteria, and when GO is coupled with Ag, it enhances its activity further. Microorganism such as Pseudomonas aeruginosa do not showed any activity with GO, but when the composite is used, its biocidal activity increases with minimum inhibitory concentration from 2.5 to $5.0 \mu \mathrm{g} / \mathrm{mL}$. This work by Andreia et al. [117] showed the first direct evidence for the action of GO-Ag, which can inhibit the growth of adhered microbial cells. These materials can also act as bio-coatings. A $\mathrm{TiO}_{2}-\mathrm{RGO}$ composite prepared by the photocatalytic reduction method was applied to F. solani spores and E. coli. The microorganism's inactivation rate was much higher than when compared to only $\mathrm{TiO}_{2}$. E. coli inactivation was observed even after the solar UVA cut-off, which was due to singlet oxygen production with the visible light excitation of $\mathrm{TiO}_{2}-\mathrm{RGO}$ [118]. Carbon nanofiber doped with $\mathrm{TiO}_{2} / \mathrm{ZnO}$ nanoparticles by electrospinning and calcination showed good antibacterial properties. The adsorption characteristics of the carbon nanofiber and the bandgap match with $\mathrm{TiO}_{2}$ and $\mathrm{ZnO}$ provides the reason for the enhanced properties of the composite [119]. Organic moieties that are coupled with GO also exhibit good antibacterial activity with B. subtilis and C. metallidurans, with the cell inactivation capacity of $92.3 \pm 10 \%$ and $99.1 \pm 1.3 \%$, respectively. Oxidative stress mechanisms toward the cell cause major bacterial inactivation [120]. The result of zero cytotoxicity with human corneal epithelial cell lines confirms the compatibility of these composites to human exposure.

\section{Oil-Water Separation and Removal using Nanofiber Membranes and Carbonaceous Materials}

Novel polysulphone electrospun nanofiber mats were used as effective membranes for oil-water separation by Obaid et al. [121]. Surface modification was done by the insertion of $\mathrm{NaOH}$ nanoparticles, and the formation of thin polyamide polymers. The insertion of thin layers decreases the contact angle, and shows a good degree of efficiency with oil-water separation at a relatively high water flux of $5.5 \mathrm{~m}^{3} / \mathrm{m}^{2}$ day. Similar studies was conducted by Caili et al., using PIM-1/ polyhedral oligomeric silsesquioxane (POSS). The membrane showed superhydrophobic-superoleophilic properties when the POSS concentration increased to $40 \%$. The membrane showed a tremendous degree of efficiency towards the oil-water mixture of up to $99.95 \%$, and it extended the separation of water-in-oil emulsions with greater efficacy (99.97\%) (Figure 2). This membrane was also subjected toward dye absorption from oils, and it exhibited an adsorption capacity of about $8.33 \mathrm{mg} / \mathrm{g}$ for Blue 35, and $7.49 \mathrm{mg} / \mathrm{g}$ for Oil Red [122]. When the microfiber was dip-coated with fluorinated alkylsilane and PIM-1, the membrane surface was modified to show a superhydrophobic surface, and resulting in the successful separation of oil and water, with a maximum separation capacity of $99.96 \%$ [123].

Similarly, the immersion of a PVDF membrane into aqueous dopamine solution for a day showed stable superoleophobicity in sea water, with an oil contact angle of $152 \pm 0.3^{\circ}$. The membrane showed high oil-water separation, and high permeability [124]. Conventional UF membranes were compared with TFC membranes by Mehrdad et al. Efficient flux and rejection of both membranes were identified, and they showed that the TFC's pure flux rose from $20 \%$ to $160 \%$, in comparison to Polysulfone (PSF) asymmetric membrane [125]. Poly(vinylidenefluoride-co-hexafluoropropylene) (PVDF-Co-HFP) nanofibers modified with cellulose were studied for oil-water separation by Farah et al. [126]. Great control of porosity and wettability were observed for the 3D-impregnated cellulose, and at $15 \mathrm{wt} \%$ cellulose, the modulus and the tensile strength increased from $17 \mathrm{MPa}$ to $54 \mathrm{MPa}$, and from $5.5 \mathrm{mPa}$ to $8.6 \mathrm{mPa}$, respectively. It showed about $99.98 \%$ oil-water separation efficiency.

Graphene/CNT aerogels with 3D interconnects were reported for efficient oil-water removal. The reduction of GO and acid-treated CNT by ferrous ions was employed, and it exhibited outstanding performance for the removal of petroleum products, fats, and organic solvents. The aerogel showed the capacity for removing $28 \mathrm{~L}$ of oil/g [127]. GOs functionalized with ePOSS (epoxy-functionalized polyhedral oligomeric silsesquioxane) with a strong super hydrophobic (contact angle of $\sim 145^{\circ}$ ) nature were tested over the oil-water separation (Scheme 5) [128]. 


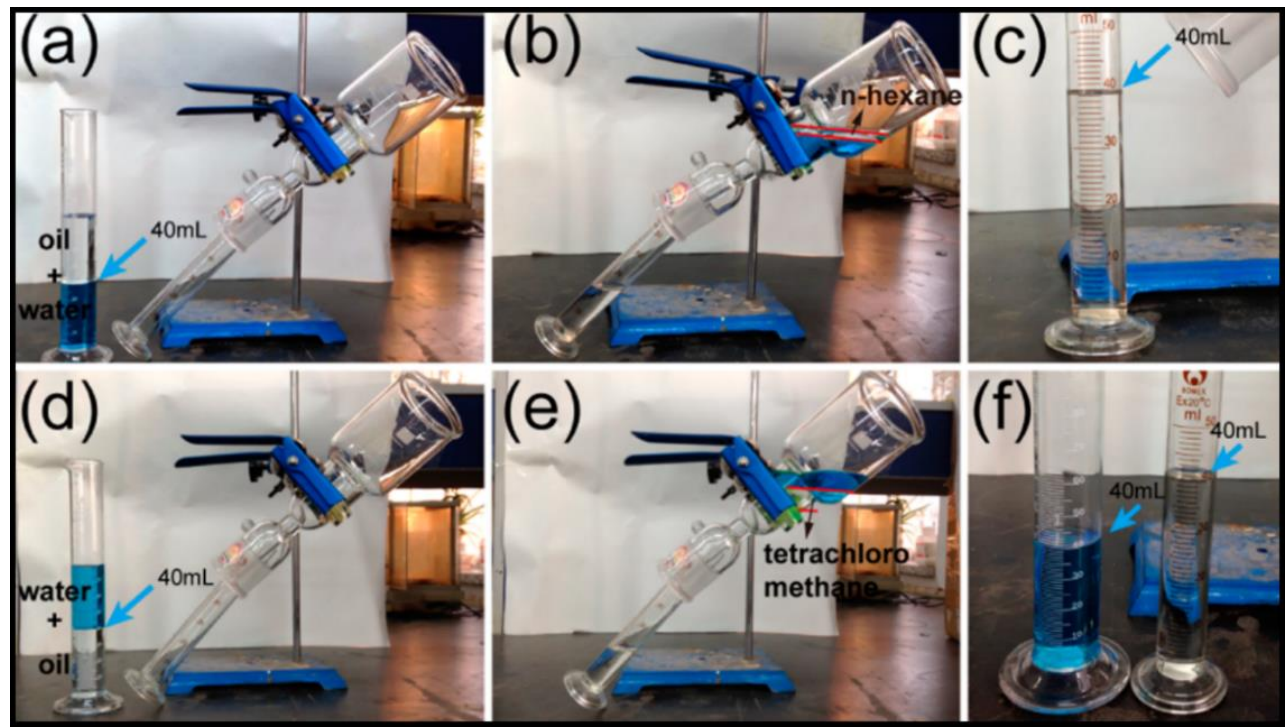

Figure 2. Photographs of the oil-water separation process: (a) a membrane fixed between a glass tube and a conical flask with a tilt angle of $45^{\circ},(\mathbf{b})$ a mixture of $n$-hexane $(40 \mathrm{~mL})$ and water $(40 \mathrm{~mL})$ poured into an upper glass tube and $n$-hexane passing through the membrane but water repelled, (c) hexane collected in a measuring cylinder after separation, $(\mathbf{d}-\mathbf{f})$ a similar process for separating tetrachloromethane (heavier than water) and water (water dyed with methyl blue). Adopted from Ref. [122].

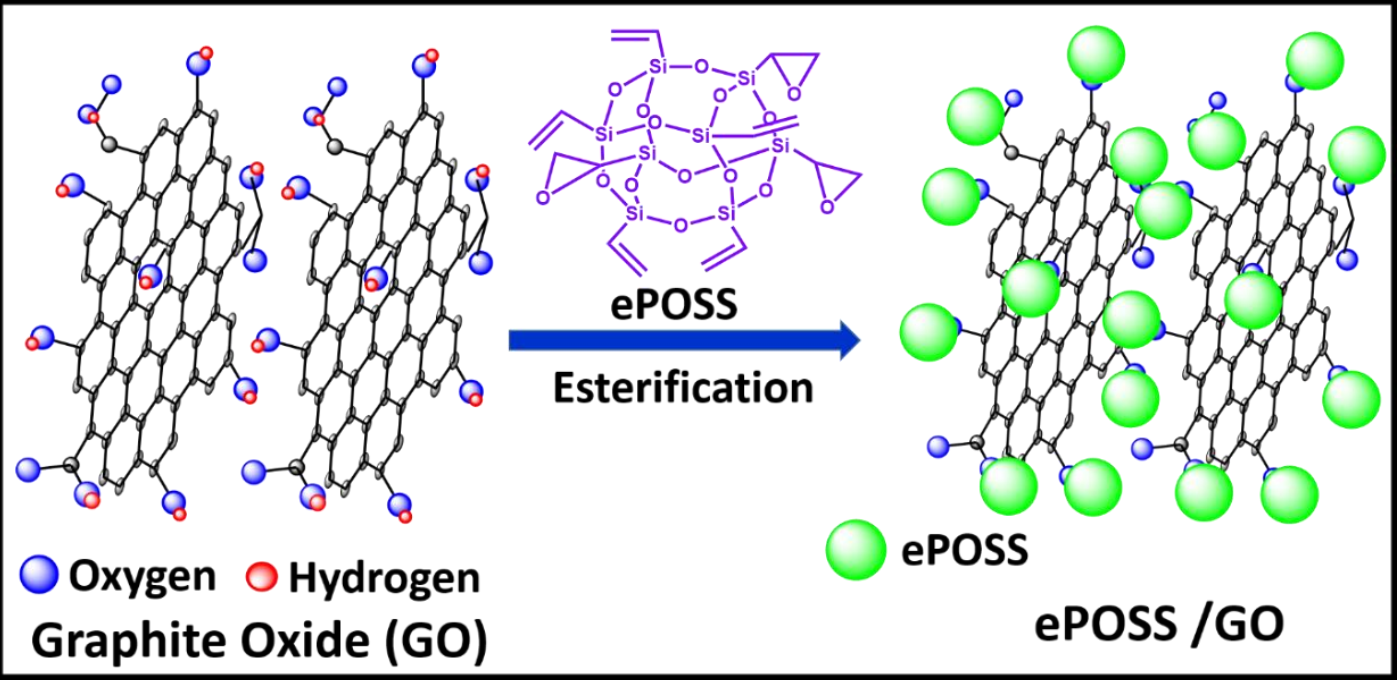

Scheme 5. Esterification of GO with ePOSS Adopted from Ref. [128].

Another report on $\mathrm{Al}_{2} \mathrm{O}_{3}$-modified $\mathrm{GO}$ to address the high permeate flux and oil rejection in oil/water emulsions was published by Xuebing et al. [129]. GOs were coated on $\mathrm{Al}_{2} \mathrm{O}_{3}$ membranes homogenously, therefore resulting in a covalent bond formation between the membrane and GO. A high flux rate of 522 and $667 \mathrm{~L} / \mathrm{m}^{2} / \mathrm{hr}$ was observed, and this composite showed good tolerance towards effective oil water removal. Janus polymer/CNT membranes were prepared by grafting hydrophobic polystyrene and hydrophilic $N, N$-dimethylaminoethylethacrylate (PDMAEMA) with photoactive CNT membranes. Surfactant-stabilized water in oil, and oil in water emulsions were effectively separated by these membranes, due to anisotropic wettability [130].

\section{Conclusions}

Nanotechnology assists in devising many solutions for environmental issues that are considered life-threatening for current and future generations. Materials with high surface area has shown 
excellent surface properties, and exhibit tremendous efficiencies with the individual and composite materials towards solving problems. Further developments are still an ongoing process at the research level, and they focus more on addressing more complicated issues pertaining to water purification. These nanocomposites show multiple aspects for the removal of pollutants from water, and they poses positive signs for further developments. Easy techniques with more enhanced nanomaterial property will exhibit more promise for use in water separation and purification. Recent trends in 2D and 3D materials create many pathways for careful engineering of materials for target pollutants. The chemical or physical modification of these 2D materials will contribute more towards the processes and the resources for cleaning water.

Funding: This research received no external funding.

Acknowledgments: The authors gratefully acknowledge the Department of Mechanical engineering \& NUS Nanoscience and Nanotechnology Initiative, National University of Singapore.

Conflicts of Interest: The authors declare no conflict of interest.

\section{References}

1. UN Water- Coordinating the UN's Work on Water and Sanitation. Available online: http:/ / www.unwater. org/statistics/en/ (accessed on 14 March 2019).

2. Li, X.; Qi, Y.; Li, Y.; Zhang, Y.; He, X.; Wang, Y. Novel magnetic beads based on sodium alginate gel crosslinked by zirconium(IV) and their effective removal for $\mathrm{Pb}^{2+}$ in aqueous solutions by using a batch and continuous systems. Bioresour. Technol. 2013, 142, 611-619. [CrossRef]

3. Culp, S.J.; Blankenship, L.R.; Kusewitt, D.F.; Doerge, D.R.; Mulligan, L.T.; Beland, F.A. Toxicity and metabolism of malachite green and leucomalachite green during short-term feeding to Fischer 344 rats and B6C3F1 mice. Chem.-Biol. Interact. 1999, 122, 153-170. [CrossRef]

4. Ngwuluka, N.C.; Ochekpe, N.A.; Odumosu, P.O. An assessment of pharmaceutical waste management in some Nigerian pharmaceutical industries. Afr. J. Biotechnol. 2011, 10, 11259-11264. [CrossRef]

5. Tania, D. Nanotechnology for Water Purification; Brown Walker Press: Boca Raton, FL, USA, 2012; Volume 1, pp. 1-29.

6. Madadrang, C.J.; Kim, H.Y.; Gao, G.; Wang, N.; Zhu, J.; Feng, H.; Gorring, M.; Kasner, M.L.; Hou, S. Adsorption Behavior of EDTA-Graphene Oxide for Pb (II) Removal. ACS Appl. Mater. Interface 2012, 4, 1186-1193. [CrossRef] [PubMed]

7. Abdel-Halim, S.H.; Shehata, A.M.A.; El-Shahat, M.F. Removal of lead ions from industrial waste water by different types of natural materials. Water Res. 2003, 37, 1678-1683. [CrossRef]

8. Xu, M.; Hadi, P.; Chen, G.; McKay, G. Removal of cadmium ions from wastewater using innovative electronic waste-derived material. J. Hazard. Mater. 2014, 273, 118-123. [CrossRef] [PubMed]

9. Wang, J.; Xu, W.; Chen, L.; Huang, X.; Liu, J. Preparation and evaluation of magnetic nanoparticles impregnated chitosan beads for arsenic removal from water. Chem. Eng. J. 2014, 251, 25-34. [CrossRef]

10. Awual, M.R. A novel facial composite adsorbent for enhanced copper (II) detection and removal from wastewater. Chem. Eng. J. 2015, 266, 368-375. [CrossRef]

11. Ravindra, K.G.; Pavan, K.G.; Sushmita, B.; Shivani, S.; Sanjeev, K.S.; Mahesh, C.C. Removal of Ni(II) by magnetic nanoparticles. J. Mol. Liq. 2015, 204, 60-69.

12. Sneha, L.; Shripal, S.; Amalendu, S. Magnetic iron oxide $\left(\mathrm{Fe}_{3} \mathrm{O}_{4}\right)$ nanoparticles from tea waste for arsenic removal. J. Magn. Magn. Mater. 2014, 356, 21-31.

13. Mark, A.B.; Stephen, C.D.V. Predicting azo dye toxicity. Crit. Rev. Environ. Sci. Technol. 1993, 23, 249-324.

14. Nafarethinam, K.; Mariappan, M.S. Kinetics and mechanism of removal of methylene blue by adsorption on various carbons-A comparative study. Dyes Pigments 2001, 51, 25-40.

15. Badr, Y.; Abd El-Wahed, M.G.; Mahmoud, M.A. Photocatalytic degradation of methyl red dye by silica nanoparticles. J. Hazard. Mater. 2008, 154, 245-253. [CrossRef] [PubMed]

16. Fontenot, B.E.; Hunt, L.R.; Hildenbrand, Z.L.; Carlton, D.D., Jr; Oka, H.; Walton, J.L.; Hopkins, D.; Osorio, A.; Bjorndal, B.; Hu, Q.H.; et al. An evaluation of water quality in private drinking water wells near natural gas extraction sites in the Barnett shale formation. Environ. Sci. Technol. 2013, 47, 10032-10040. [CrossRef]

17. Stephen, G.O.; Avner, V.; Nathaniel, R.W.; Robert, B.J. Methane contamination of drinking water accompanying gas-well drilling and hydraulic fracturing. Proc. Natl. Acad. Sci. USA 2011, 108, 8172-8176. 
18. Marisa, P.; Anbarasan, A.; Rosa, A.B.; Britt, M.S.; Maria, J.; Bo, M. Degradation of a textile azo dye using biological treatment followed by photo-Fenton oxidation: Evaluation of toxicity and microbial community structure. Chem. Eng. J. 2015, 270, 290-299.

19. Dong, Y.; Su, Y.; Chen, W.; Peng, J.; Zhang, Y.; Jang, Z. Ultrafiltration Enhanced with Activated Carbon Adsorption for Efficient Dye Removal from Aqueous Solution. Chin. J. Chem. Eng. 2011, 19, 863-869. [CrossRef]

20. Lee, Y.C.; Kim, E.J.; Yang, J.W.; Shin, H.J. Removal of malachite green by adsorption and precipitation using amino propyl functionalized magnesium phyllosilicate. J. Hazard. Mater. 2011, 192, 62-70.

21. Anca, D.; Maria, V. Simultaneous removal of two industrial dyes by adsorption and photocatalysis on a fly-ash-TiO 2 composite. J. Photochem. Photobiol. A Chem. 2015, 306, 21-30.

22. Harold, F.U. The Deepwater Horizon Oil Spill and the Gulf of Mexico Fishing Industry. 2011. Available online: https:/ / fas.org/sgp/crs/misc/R41640.pdf (accessed on 14 March 2019).

23. Peng, H.; Tremblay, A.Y.; Veinot, D.E. The use of back flushed coalescing microfiltration as a pretreatment for the ultrafiltration of bilge water. Desalination 2005, 181, 109-120. [CrossRef]

24. Sundarrajan, S.; Ramakrishna, S. New Directions in Nanofiltration Applications-Are Nanofibers the Right Materials as Membranes in Desalination? Desalination 2013, 308, 198-208.

25. Ramalingam, B.; Subramanian, S.; Seeram, R. Recent Trends in Nanofibrous Membranes and Their Suitability for Air and Water Filtrations. Membranes 2011, 1, 232-248.

26. Shaik, A.A.N.N.; Subramanian, S.; Syed, A.S.N.; Ramalingam, B.; Seeram, R. Advancement in Electrospun Nanofibrous Membranes Modification and Their Application in Water Treatment. Membranes 2013, 3, 266-284.

27. Renuga, G.; Satinderpal, K.; Chao, Y.F.; Casey, C.; Seeram, R.; Shahram, T.; Takeshi, M. Electrospun nanofibrous polysulfone membranes as pre-filters: Particulate removal. J. Membr. Sci. 2007, 289, $210-219$.

28. Liu, Y.; Wang, R.; Ma, H.; Hsiao, B.S.; Chu, B. High-flux microfiltration filters based on electrospun poly vinyl alcohol nanofibrous membranes. Polymer 2013, 54, 548-556. [CrossRef]

29. Ma, H.; Burger, C.; Hsiao, B.S.; Chu, B. Ultra-fine cellulose nanofibers: New nano-scale materials for water purification. J. Mater. Chem. 2011, 21,7507-7510. [CrossRef]

30. Shaik, A.A.N.N.; Subramanian, S.; Syed, A.S.N.; Ramalingam, B.; Seeram, R. In situ polymerization of PVDF-HEMA polymers: Electrospun membranes with improved flux and antifouling properties for water filtration. Polym. J. 2014, 46, 167-174.

31. Li, M.; Xue, X.; Wang, D.; Lu, Y.; Wu, Z.; Zou, H. High performance filtration nanofibrous membranes based on hydrophilic poly (vinyl alcohol-co-ethylene) copolymer. Desalination 2013, 329, 50-56. [CrossRef]

32. Sang, Y.; Gu, Q.; Sun, T.; Li, F.; Liang, C. Filtration by a novel nanofiber membrane and alumina adsorption to remove copper (II) from groundwater. J. Hazard. Mater. 2008, 153, 860-866. [CrossRef] [PubMed]

33. Wang, J.; Luo, C.; Qi, G.; Pan, K.; Cao, B. Mechanism study of selective heavy metal ion removal with polypyrrole-functionalized polyacrylonitrile nanofiber mats. Appl. Surf. Sci. 2014, 316, 245-250. [CrossRef]

34. He, X.; Cheng, L.; Wang, Y.; Zhao, J.; Zhang, W.; Lu, C. Aerogels from quaternary ammonium functionalized cellulose nanofibers for rapid removal of $\mathrm{Cr}(\mathrm{VI})$ from water. Carbohydr. Polym. 2014, 111, 683-687. [CrossRef] [PubMed]

35. Feng, Q.; Wu, D.; Zhao, Y.; Wei, A.; Wei, Q.; Fong, H. Electrospun AOPAN/RC blend nanofiber membrane for efficient removal of heavy metal ions from water. J. Hazard. Mater. 2018, 344, 819-828. [CrossRef]

36. Wang, G.; Zhang, H.; Wang, J.; Ling, Z.; Qiu, J. In situ synthesis of chemically active ZIF coordinated with electrospun fibrous film for heavy metal removal with a high flux. Sep. Purif. Technol. 2017, 177, 257-262. [CrossRef]

37. Wang, X.; Yeh, T.M.; Wang, Z.; Yang, R.; Wang, R.; Ma, H.; Hsiao, B.S.; Chu, B. Nanofiltration membranes prepared by interfacial polymerization on thin-film nanofibrous composite scaffold. Polymer 2014, 55, 1358-1366. [CrossRef]

38. Yoon, K.; Hsiao, B.S.; Chu, B. High flux nanofiltration membranes based on interfacially polymerized polyamide barrier layer on polyacrylonitrile nanofibrous scaffolds. J. Membr. Sci. 2009, 326, 484-492. [CrossRef]

39. Cheng, H.L.; Chang, L.C.; Shih, J.L. Electrospun nanofibrous rhodanine/polymethylmethacrylate membranes for the removal of heavy metal ions. Sep. Purif. Technol. 2013, 118, 737-743.

40. Iman, Y.S.; Sagar, T.; Kennedy, O.; Ola, A.M.; Adam, K.W. Polymeric nanofibers for the removal of Cr (III) from tannery waste water. J. Environ. Manag. 2013, 129, 410-413. 
41. Arash, T.; Mohammad, K.P.; Munir, A.; Zohreh, P. New efficient inorganic-organic nanofibers electrospun membrane for fluorescence detection and removal of mercury (II) ions. J. Mol. Struct. 2019, 1179, 242-251.

42. Rathinam, K.; Sankaran, M. Removal of $\mathrm{Pb}$ (II) and Cd (II) ions from aqueous solution usingpolyaniline grafted chitosan. Chem. Eng. J. 2015, 63, 168-177.

43. Yang, D.; Li, L.; Chen, B.; Shi, S.; Nie, J.; Ma, G. Functionalized chitosan electrospun nanofiber membranes for heavy-metal removal. Polymer 2019, 163, 74-85. [CrossRef]

44. Yoo, H.; Kwak, S.Y. Surface functionalization of PTFE membranes with hyperbranched poly (amidoamine) for the removal of $\mathrm{Cu}^{2+}$ ions from aqueous solution. J. Membr. Sci. 2013, 448, 125-134. [CrossRef]

45. Abdouss, M.; Mousavi Shoushtari, A.; Majidi Simakani, A.; Akbari, S.; Haji, A. Citric acid-modified acrylicmicro and nanofibers for removal of heavy metal ions from aqueous media. Desalination Water Treat. 2014, 52, 7133-7142. [CrossRef]

46. Liu, D.; Zhu, Y.; Li, Z.; Tian, D.; Chen, L.; Chen, P. Chitin nanofibrils for rapid and efficient removal of metal ions from water system. Carbohydr. Polym. 2013, 98, 483-489. [CrossRef] [PubMed]

47. Rad, L.R.; Momeni, A.; Ghazani, B.F.; Irani, M.; Mahmoudi, M.; Noghreh, B. Removal of $\mathrm{Ni}^{2+}$ and $\mathrm{Cd}^{2+}$ ions from aqueous solutions using electrospun PVA/zeolite nanofibrous adsorbent. Chem. Eng. J. 2014, 256, 119-127. [CrossRef]

48. Zhao, R.; Li, X.; Sun, B.; Shen, M.; Tan, X.; Ding, Y.; Jiang, Z.; Wang, C. Preparation of phosphorylated polyacrylonitrile-based nanofiber mat and its application for heavy metal ion removal. Chem. Eng. J. 2015, 268, 290-299. [CrossRef]

49. Zhou, W.; He, J.; Cui, S.; Gao, W. Preparation of electrospun silk fibroin/Cellulose Acetate blend nanofibers and their applications to heavy metal ions adsorption. Fibers Polym. 2011, 12, 431-437. [CrossRef]

50. Xu, J.; Zhang, H.; Zhang, J.; Kim, E.J. Capture of toxic radioactive and heavy metal ions from water by using titanate nanofibers. J. Alloys Compd. 2014, 614, 389-393. [CrossRef]

51. Mahapatra, A.; Mishra, B.G.; Hota, G. Electrospun $\mathrm{Fe}_{2} \mathrm{O}_{3}-\mathrm{Al}_{2} \mathrm{O}_{3}$ nanocomposite fibers as efficient adsorbent for removal of heavy metal ions from aqueous solution. J. Hazard. Mater. 2013, 258-259, 116-123. [CrossRef]

52. Sounthararajah, D.P.; Loganathan, P.; Kandasamy, J.; Vigneswaran, S. Adsorptive removal of heavy metals from water using sodium titanate nanofibers loaded onto GAC in fixed-bed columns. J. Hazard. Mater. 2015, 287, 306-316. [CrossRef]

53. Ma, H.; Hsiao, B.S.; Chu, B. Functionalized electrospun nanofibrous microfiltration membranes for removal of bacteria and viruses. J. Membr. Sci. 2014, 452, 446-452. [CrossRef]

54. Chen, Y.; Zhang, Y.; Liu, J.; Zhang, H.; Wang, K. Preparation and antibacterial property of Polyethersulfone ultrafiltration hybrid membrane containing halloysite nanotubes loaded with copper ions. Chem. Eng. J. 2012, 210, 298-308. [CrossRef]

55. Almajhdi, F.N.; Fouad, H.; Khalil, K.A.; Awad, H.M.; Mohamed, S.H.S.; Elsarnagawy, T.; Albarrag, A.M.; Al-Jassir, F.F.; Abdo, H.S. In-vitro anticancer and antimicrobial activities of PLGA/silver nanofiber composites prepared by electrospinning. J. Mater. Sci. 2014, 25, 1045-1053. [CrossRef] [PubMed]

56. Pant, H.R.; Pandeya, D.R.; Nam, K.T.; Baek, W.I.; Hong, S.T.; Kim, H.Y. Photocatalytic and antibacterial properties of a $\mathrm{TiO}_{2}$ /nylon-6 electrospun nanocomposite mat containing silver nanoparticles. J. Hazard. Mater. 2011, 189, 465-471. [CrossRef]

57. Gilchrist, S.E.; Lange, D.; Letchford, K.; Bach, H.; Fazli, L.; Burt, H.M. Fusidic acid and rifampicin co-loaded PLGA nanofibers for the prevention of orthopedic implant associated infections. J. Control. Release 2013, 170, 64-73. [CrossRef] [PubMed]

58. Daels, N.; De Vrieze, S.; Sampers, I.; Decostere, B.; Westbroek, P.; Dumoulin, A.; Dejans, P.; De Clerck, K.; Van Hulle, S.W.H. Potential of a functionalized nanofiber microfiltration membrane as an antibacterial water filter. Desalination 2011, 275, 285-290. [CrossRef]

59. Yao, C.; Li, X.; Neoh, K.G.; Shi, Z.; Kang, E.T. Surface modification and antibacterial activity of electrospun polyurethane fibrous membranes with quaternary ammonium moieties. J. Membr. Sci. 2008, 320, 259-267. [CrossRef]

60. Mei, Y.; Yao, C.; Fan, K.; Li, X. Surface modification of polyacrylonitrile nanofibrous membranes with superior antibacterial and easy-cleaning properties through hydrophilic flexible spacers. J. Membr. Sci. 2012, 417-418, 20-27. [CrossRef]

61. Heinz, L. Color Chemistry: Synthesis, Properties and Applications of Organic Dyes and Pigmens; VCH Publishes: New York, NY, USA, 1987; pp. 92-100. 
62. Patel, S.; Hota, G. Adsorptive Removal of Malachite Green Dye by Functionalized Electrospun PAN Nanofibers Membrane. Fibers Polym. 2014, 15, 2272-2282. [CrossRef]

63. Almasian, A.; Olya, M.E.; Mahmoodi, N.M. Synthesis of polyacrylonitrile/polyamidoamine composite nanofibers using electrospinning technique and their dye removal capacity. J. Taiwan Inst. Chem. Eng. 2015, 49, 119-128. [CrossRef]

64. Li, X.; Li, Y.; Zhang, S.; Ye, Z. Preparation and characterization of new foam adsorbents of poly (vinyl alcohol)/chitosan composites and their removal for dye and heavy metal from aqueous solution. Chem. Eng. J. 2012, 183, 88-97. [CrossRef]

65. Basiri, F.; Abdolkarim, H.R.S.; Feiz, M.; Moheb, A. Recycling of Direct Dyes Wastewater by Nylon-6 Nanofibrous Membrane. Curr. Nanosci. 2011, 7, 633-639. [CrossRef]

66. Fu, G.; Su, Z.; Jiang, X.; Yin, J. Photo cross-linked nanofibers of poly (ether amine) (PEA) for the ultrafast separation of dyes through molecular filtration. Polym. Chem. 2014, 5, 2027-2034. [CrossRef]

67. Mozhdeh, G.; Ali Akbar, G.; Mokhtar, A.; Negar, T.; Babak, R. Fabrication of Electrospun Polyamide-6/Chitosan Nanofibrous Membrane toward Anionic Dyes Removal. J. Nanotech. 2014, 278418. [CrossRef]

68. Liu, L.; Liu, Z.; Bai, H.; Sun, D.D. Concurrent filtration and solar photocatalytic disinfection/degradation using high-performance $\mathrm{Ag} / \mathrm{TiO}_{2}$ nanofiber membrane. Water Res. 2012, 46, 1101-1112. [CrossRef] [PubMed]

69. Wang, Q.; Gao, D.; Gao, C.; Wei, Q.; Cai, Y.; Xu, J.; Liu, X.; Xu, Y. Removal of a Cationic Dye by Adsorption/Photo degradation Using Electrospun PAN/O-MMT Composite Nanofibrous Membranes Coated with $\mathrm{TiO}_{2}$. Int. J. Photoenergy 2012, 2012. [CrossRef]

70. Aluigi, A.; Rombaldoni, F.; Tonetti, C.; Jannoke, L. Study of Methylene Blue adsorption on keratin nanofibrous membranes. J. Hazard. Mater. 2014, 268, 156-165. [CrossRef]

71. Xu, Y.; Bao, J.; Zhang, X.; Li, W.; Xie, Y.; Sun, S.; Zhao, W.; Zhao, C. Functionalized polyethersulfone nanofibrous membranes with ultra-high adsorption capacity for organic dyes by one-step electrospinning. J. Colloid Interface Sci. 2019, 533, 526-538. [CrossRef]

72. Bai, L.; Jia, L.; Yan, Z.; Liu, Z.; Liu, Y. Plasma-etched electrospun nanofiber membrane as adsorbent for dye removal. Chem. Eng. Res. Des. 2018, 132, 445-451. [CrossRef]

73. Bekir, S.; Peter, M.B.; Tamer, U. Systematic hydrolysis of PIM-1 and electrospinning of hydrolyzed PIM-1 ultrafine fibers for an efficient removal of dye from water. React. Funct. Polym. 2017, 121, 67-75.

74. Chaúque, E.F.; Dlamini, L.N.; Adelodun, A.A.; Greyling, C.J.; Ngila, J.C. Electrospun polyacrylonitrile nanofibers functionalized with EDTA for adsorption of ionic dyes. Phys. Chem. Earth Parts A/B/C 2017, 100, $201-211$.

75. Zhang, J.; Zhai, S.; Li, S.; Xiao, Z.; Song, Y.; An, Q.; Tian, G. Pb (II) removal of $\mathrm{Fe}_{3} \mathrm{O}_{4} @ \mathrm{SiO}_{2}-\mathrm{NH}_{2}$ core-shell nanomaterials prepared via controllable sol-gel process. Chem. Eng. J. 2013, 215-216, 461-471. [CrossRef]

76. Madhu, K.; Charles, U.P.; Dinesh, M. Heavy metals [chromium (VI) and lead (II)] removal from water using mesoporous magnetite $\left(\mathrm{Fe}_{3} \mathrm{O}_{4}\right)$ nanospheres. J Colloid Interface Sci. 2015, 442, 120-132.

77. Ali, A.; Shahriar, H.; Ahmad, R.M.; Emaeel, D.; Houshang, A.H. Optimization of heavy metal removal from aqueous solutions by maghemite $\left(\gamma-\mathrm{Fe}_{2} \mathrm{O}_{3}\right)$ nanoparticles using response surface methodology. J. Geochem. Explor. 2014, 147, 151-158.

78. Negin, G.; Sayed, S.M.; Parisa, D.; Hamid, R.; Sirus, Z.; Abdolhamid, A.; Rouhollah, H.; Mojtaba, B.; Sohrab, G. Polyethersulfone membrane enhanced with iron oxide nanoparticles for copper removal from water: Application of new functionalized $\mathrm{Fe}_{3} \mathrm{O}_{4}$ nanoparticles. Chem. Eng. J. 2015, 263, 101-112.

79. Cai, X.; Gao, Y.; Sun, Q.; Chen, Z.; Megharaj, M.; Naidu, R. Removal of co-contaminants Cu (II) and nitrate from aqueous solution using kaolin-Fe/Ni nanoparticles. Chem. Eng. J. 2014, 244, 19-26. [CrossRef]

80. Phuengprasop, T.; Sittiwong, J.; Unob, F. Removal of heavy metal ions by iron oxide coated sewage sludge. J. Hazard. Mater. 2011, 186, 502-507. [CrossRef]

81. Yoann, G.; Ahmad, B.A.; Jose, G.; Eghe, O.; Chirangano, M.; Claire, G.; Stephen, J.A.; Gavin, M.W. Adsorption study using optimized 3D organized mesoporous silica coated with Fe and Al oxides for specific As(III) and $\mathrm{As}(\mathrm{V})$ removal from contaminated synthetic groundwater. Microporous Mesoporous Mater. 2014, 198, 101-114.

82. Dadfarnia, S.; Shabani, A.M.H.; Moradi, S.E.; Emami, S. Methyl red removal from water by iron based metal-organic frameworks loaded onto iron oxide nanoparticle adsorbent. Appl. Surf. Sci. 2015, 330, 85-93. [CrossRef]

83. Jia, Z.; Liu, J.; Wang, Q.; Li, S.; Qi, Q.; Zhu, R. Synthesis of 3D hierarchical porous iron oxides for adsorption of Congo red from dye wastewater. J. Alloys Compd. 2015, 622, 587-595. [CrossRef] 
84. Mahapatra, A.; Mishra, B.G.; Hota, G. Adsorptive removal of Congo red dye from waste water by mixed iron oxide- alumina nanocomposites. Ceram. Int. 2013, 39, 5443-5451. [CrossRef]

85. Kumar, K.Y.; Muralidhara, H.B.; Nayaka, YA.; Balasubramanyam, J.; Hanumanthappa, H. Lowcost synthesis of metal oxide nanoparticles and their application in adsorption of commercial dye and heavy metal ion in aqueous solution. Powder Technol. 2013, 246, 125-136. [CrossRef]

86. Al-Nakib, C.; Abdur, R.; Yusuf, J.F.; Md.Shafiul, A.; Mufazzal, H.M. Cobalt-nickel mixed oxide surface: A promising adsorbent for the removal of PR dye from water. Appl. Surf. Sci. 2010, 256, 3718-3724.

87. Gupta, V.K.; Agarwa, S.; Pathania, D.; Kothiyal, N.C.; Sharma, G. Use of pectin-thorium (IV) tungstomolybdate nanocomposite for photocatalytic degradation of methylene blue. Carbohydr. Polym. 2013, 96, 277-283. [CrossRef] [PubMed]

88. Jiang, Y.; Tang, W.; Gao, J.; Zhou, L.; He, Y. Immobilization of horseradish peroxidase in phospholipid-templated Titania and its applications in phenolic compounds and dye removal. Enzym. Microb. Technol. 2014, 55, 1-6. [CrossRef] [PubMed]

89. Sarika, S.; Barick, K.C.; Bahadur, D. $\mathrm{Fe}_{3} \mathrm{O}_{4}$ embedded $\mathrm{ZnO}$ nanocomposites for the removal of toxic metal ions, organic dyes and bacterial pathogens. J. Mater. Chem. A 2013, 1, 3325-3333.

90. Chen, D.; Li, Y.; Zhang, J.; Li, W.; Zhou, J.; Shao, L.; Qian, G. Efficient removal of dyes by a novel magnetic $\mathrm{Fe} 3 \mathrm{O} 4 / \mathrm{ZnCr}-\mathrm{layered}$ double hydroxide adsorbent from heavy metal wastewater. J. Hazard. Mater. 2012, 243, 152-160. [CrossRef] [PubMed]

91. Tseng, W.J.; Lin, R.D. $\mathrm{BiFeO}_{3} / \alpha-\mathrm{Fe}_{2} \mathrm{O}_{3}$ core/shell composite particles for fast and selective removal of methyl orange dye in water. J. Colloid Interface Sci. 2014, 428, 95-100. [CrossRef] [PubMed]

92. Hye, J.H.; Jungmin, K.; Jung, S.Y.; Eun, J.K.; Jin, W.Y. Removal of Anionic and Cationic Dyes from Water by Fe-Al Binary Oxide. Sep. Sci. Technol. 2012, 47, 2218-2224.

93. Chen, L.; Song, Z.; Wang, X.; Prikhodko, S.V.; Hu, J.; Kodambaka, S.; Richards, R. Three-Dimensional Morphology Control during Wet Chemical Synthesis of Porous Chromium Oxide Spheres. ACS Appl. Mater. Interfaces 2009, 1, 1931-1937. [CrossRef] [PubMed]

94. Rutala, W.A.; Weber, D.J.; The Healthcare Infection Control Practices Advisory Committee (HICPAC). Guide for Disinfection and Sterilization in Health Care Facilities; CDC: Atlanta, GA, USA, 2008.

95. Tamar, G.; Benny, P.; Ofir, H.; Israel, F.; Ehud, B.; Shlomo, M. Synthesis and characterization of zinc/iron oxide composite nanoparticles and their antibacterial properties. Colloid Surf. A Physicochem. Eng. Asp. 2011, 374, 1-8.

96. Antony, A.; Subramanian, D.; Moon, S.H.; Young, S.M. Copper oxide nanomaterials: Synthesis, characterization and structure-specific antibacterial performance. Chem. Eng. J. 2015, 262, 179-188.

97. Amin, Y.B.; Rong, W.; Rong, X. Simple method of deposition of CuO nanoparticles on a cellulose paper and its antibacterial activity. Chem. Eng. J. 2015, 262, 999-1008.

98. Jasna, H.; Jelena, M.; Nina, D.; Renata, M.K.; Nevenka, R. Antimicrobial activity of metal oxide nanoparticles supported onto natural clinoptilolite. Chemosphere 2012, 88, 1103-1107.

99. Zhang, L.; Pei, Y.T.; Chee, L.C.; Chiew, K.L.; Ooi, K.T.; Man, S.T.; Chun, C.S. Antibacterial activities of mechanochemically synthesized perovskite strontium titanate ferrite metal oxide. Colloid Surf. A Physicochem. Eng. Asp. 2014, 456, 169-175. [CrossRef]

100. Cui, L.; Guo, X.; Wei, Q.; Wang, Y.; Gao, L.; Yan, L.; Yan, T.; Du, B. Removal of mercury and methylene blue from aqueous solution by xanthate functionalized magnetic graphene oxide: Sorption kinetic and uptake mechanism. J. Colloid Interface Sci. 2015, 439, 112-120. [CrossRef]

101. Sreeprasad, T.S.; Shihabudheen, M.M.; Lisha, K.P.; Pradeep, T. Reduced graphene oxide-metal/metal oxide composites: Facile synthesis and application in water purification. J. Hazard. Mater. 2011, 186, 921-931. [CrossRef] [PubMed]

102. Zabihi, M.; Ahmadpour, A.; Asl, A.H. Removal of mercury from water by carbonaceous sorbents derived from walnut shell. J. Hazard. Mater. 2009, 67, 230-236. [CrossRef]

103. Jiu, H.D.; Xiu, R.Z.; Guang, M.Z.; Ji, L.G.; Qiu, Y.N.; Jie, L. Simultaneous removal of Cd(II) and ionic dyes from aqueous solution using magnetic graphene oxide nanocomposite as an adsorbent. Chem. Eng. J. 2013, 226, 189-200.

104. Fu, Y.; Wang, J.; Liu, Q.; Zeng, H. Water-dispersible magnetic nanoparticle-graphene oxide composites for selenium removal. Carbon 2014, 77, 710-721. [CrossRef] 
105. Mohamed, E.M.; Maher, M.O.; Somia, B.A.; Tarek, M.A. Improved adsorptive removal of cadmium from water by hybrid chemically and biologically carbonaceous sorbents. Chem. Eng. J. 2011, 175, 84-94.

106. Mona, K.; Ahmad, K.; Hanafy, H.; Zakia, O. Heavy Metals Removal Using Activated Carbon, Silica and Silica Activated Carbon Composite. Energy Procedia 2014, 50, 113-120.

107. Ashish, K.M.; Ramaprabhu, S. Functionalized graphene sheets for arsenic removal and desalination of sea water. Desalination 2011, 282, 39-45.

108. Wen, Y.; Ma, J.; Chen, J.; Shen, C.; Li, H.; Liu, W. Carbonaceous sulfur-containing chitosan-Fe (III): A novel adsorbent for efficient removal of copper (II) from water. Chem. Eng. J. 2015, 259, 372-380. [CrossRef]

109. Guo, X.; Du, B.; Wei, Q.; Yang, J.; Hu, L.; Yan, L.; Xu, W. Synthesis of amino functionalized magnetic graphenes composite material and its application to remove $\mathrm{Cr}(\mathrm{VI}), \mathrm{Pb}(\mathrm{II}), \mathrm{Hg}(\mathrm{II}), \mathrm{Cd}(\mathrm{II})$ and $\mathrm{Ni}(\mathrm{II})$ from contaminated water. J. Hazard. Mater. 2014, 278, 211-220. [CrossRef]

110. Renu, D.; Baipai, J.; Baipa, A.K. Green synthesis of graphene sand composite (GSC) as novel adsorbent for efficient removal of $\mathrm{Cr}$ (VI) ions from aqueous solution. J. Water Process Eng. 2015, 5, 83-94.

111. Qle, F.; Baoliang, C. Self-assembly of graphene oxide aerogels by layered double hydroxides cross-linking and their application in water purification. J. Mater. Chem. A 2014, 2, 8941-8951.

112. Luo, S.; Xu, X.; Zhou, G.; Liu, C.; Tang, Y.; Liu, Y. Amino siloxane oligomer-linked graphene oxide as an efficient adsorbent for removal of $\mathrm{Pb}$ (II) from wastewater. J. Hazard. Mater. 2014, 274, 145-155. [CrossRef] [PubMed]

113. Lei, Y.; Chen, F.; Luo, Y.; Zhang, L. Synthesis of three-dimensional graphene oxide foam for the removal of heavy metal ions. Chem. Phys./Lett. 2014, 593, 122-127. [CrossRef]

114. Nikolina, A.T.; George, Z.K.; Nikolaos, K.L.; Eleni, A.D. Graphite oxide/chitosan composite for reactive dye removal. Chem. Eng. J. 2013, 217, 256-265.

115. Wu, Z.; Zhong, H.; Yuan, X.; Wang, H.; Wang, L.; Chen, X.; Zeng, G.; Wu, Y. Adsorptive removal of methylene blue by rhamnolipid-functionalized graphene oxide from Wastewater. Water Res. 2014, 67, 330-344. [CrossRef] [PubMed]

116. Robert, L.; Anming, H.; Melisa, H.F.; Norman, Z. Fundamentals on Adsorption, Membrane Filtration, and Advanced Oxidation Processes for Water Treatment. Nanotechnol. Water Treat. Purif. 2014, 22, 1-45.

117. Andreia, F.F.; Diego, S.T.M.; Stela, M.M.M.; Ana, C.M.M.; Adriano, B.; Antonio, G.S.F.; Oswaldo, L.A. Anti-adhesion and antibacterial activity of silver nanoparticles supported on grapheme oxide sheets. Colloids Surf. B Biointerfaces 2014, 113, 115-124.

118. Fernandez-Ibanez, P.; Polo-Lopez, M.I.; Malato, S.; Wadhwa, S.; Hamilton, J.W.J.; Dunlop, P.S.M.; D'Sa, R.; Magee, E.; Shea, K.O.; Dionysiou, D.D. Solar photocatalytic disinfection of water using titanium dioxide graphene composites. Chem. Eng. J. 2015, 261, 36-44. [CrossRef]

119. Bishweshwar, P.; Hem, R.P.; Nasser, AM.B.; Mira, P.; Kyungsoo, J.; Yuri, C.; Hak-yong, K. Carbon nanofibers decorated with binary semiconductor $(\mathrm{TiO} 2 / \mathrm{ZnO})$ nanocomposites for the effective removal of organic pollutants and the enhancement of antibacterial activities. Ceram. Int. 2013, 39, 7029-7035.

120. Isis, E.M.C.; Joey, D.M.; Hang, N.N.; Rigoberto, C.A.; Debora, F.R. Graphene oxide functionalized with ethylenediamine triacetic acid for heavy metal adsorption and anti-microbial applications. Carbon 2014, 77, $289-301$.

121. Obaid, M.; Nasser, A.M.B.; Fadali, O.A.; Moaaed, M.; Abdulhakim, A.A.; Khalil, A.K. Effective and reusable oil/water separation membranes based on modified polysulfone electrospun nanofiber mats. Chem. Eng. J. 2015, 259, 449-456. [CrossRef]

122. Zhang, C.; Li, P.; Cao, B. Electrospun Microfibrous Membranes Based on PIM-1/POSS with High Oil Wettability for Separation of Oil-Water Mixtures and Cleanup of Oil Soluble Contaminants. Ind. Eng. Chem. Res. 2015, 54, 8772-8781. [CrossRef]

123. Zhang, C.; Li, P.; Cao, B. Fabrication of Superhydrophobic-Superoleophilic Fabrics by an Etching and Dip-Coating Two-Step Method for Oil-Water Separation. Ind. Eng. Chem. Res. 2016, 55, 5030-5035. [CrossRef]

124. Xiang, Y.; Liu, F.; Xue, L. Under seawater superoleophobic PVDF membrane inspired by polydopamine for efficient oil/sea water separation. J. Membr. Sci. 2015, 476, 321-329. [CrossRef]

125. Mehrdad, K.; Omid, P.; Tahmasb, H. The evaluation of thin film composite membrane composed of an electrospun polyacrylonitrile nanofibrous mid-layer for separating oil-water mixture. Desalination 2015, 359, 14-21.

126. Farah, E.A.; Boor, S.L.; Nidal, H.; Raed, H. Underwater superoleophobic cellulose/electrospun PVDF-HFP membranes for efficient oil/water separation. Desalination 2014, 344, 48-54. 
127. Shervin, K.; Diana, N.H.T.; Tariq, A.; Dusan, L. Outstanding adsorption performance of graphene-carbon nanotube aerogels for continuous oil removal. Carbon 2014, 80, 523-533.

128. Liu, Y.; Zhou, J.; Zhu, E.; Tang, J.; Liu, X.; Tang, W. Covalently intercalated graphene oxide for oil-water separation. Carbon 2015, 82, 264-272. [CrossRef]

129. Hu, X.; Yu, Y.; Zhou, J.; Wang, Y.; Liang, J.; Zhang, X.; Chang, Q.; Song, L. The improved oil/water separation performance of graphene oxide modified $\mathrm{Al}_{2} \mathrm{O}_{3}$ microfiltration membrane. J. Membr. Sci. 2015, 476, $200-204$. [CrossRef]

130. Gu, J.; Xiao, P.; Chen, J.; Zhang, J.; Huang, Y.; Chen, T. Janus Polymer/Carbon Nanotube Hybrid Membranes for Oil/Water Separation. ACS Appl. Mater. Interfaces 2014, 6, 16204-16209. [CrossRef]

2019 by the authors. Licensee MDPI, Basel, Switzerland. This article is an open access article distributed under the terms and conditions of the Creative Commons Attribution (CC BY) license (http://creativecommons.org/licenses/by/4.0/). 